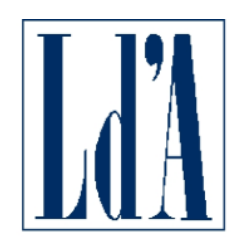

CENTRO STUDI LUCA D'AGLIANO

WWW.DAGLIANO.UNIMI.IT

\author{
CENTRO STUDI LUCA D'AGLIANO \\ DEVELOPMENT STUDIES WORKING PAPERS
}

N. 422

January 2017

The impact of China's WTO accession on internal migration

\author{
Giovanni Facchini* \\ Maggie Y. Liu** \\ Anna Maria Mayda*** \\ Minghai Zhou**** \\ * University of Nottingham, CEPR, CES-Ifo, CReAM, GEP, and LdA \\ ** Georgetown University \\ *** Georgetown University, CEPR, IZA and LdA \\ **** University of Nottingham, Ningbo China
}




\title{
The impact of China's WTO accession on internal migration*
}

\author{
Giovanni Facchini†, Maggie Y. Liuł Anna Maria Maydå Minghai Zhou
}

December 18, 2015

\begin{abstract}
In this paper we focus on the changes in internal migration flows triggered by China's 2001 entry into the World Trade Organization (WTO). We use a difference-in-difference empirical specification based on variation across Chinese prefectures before and after 2001. We relate changes in internal migration rates to the reduction in trade policy uncertainty faced by Chinese exporters to the U.S., as measured by the normal-traderelations (NTR) gap (Handley and Limao 2013, Pierce and Schott 2015). We find that Chinese prefectures facing a larger decline in their average NTR-gap experience a greater increase in internal migration. Our results also show that the impact on skilled and unskilled internal migration rates is consistent with the average skill intensity of export industries of a prefecture.

JEL classification: F22, J61. Keywords: Immigration Policy, Trade Policy, Political Economy.
\end{abstract}

*First draft: May 2015. This draft: December 2015. This paper is prepared within the "Value Added in Motion (VAM)" project funded by the Enel Foundation.

'University of Nottingham, Universita' degli Studi di Milano, CEPR, CES-Ifo, CReAM, GEP, IZA and LdA; giovanni.facchini@nottingham.ac.uk.

${ }^{\ddagger}$ Georgetown University; yl372@georgetown.edu.

${ }^{\S}$ Georgetown University, CEPR, IZA and LdA; amm224@georgetown.edu.

`University of Nottingham, Ningbo China; Minghai.Zhou@nottingham.edu.cn. 


\section{Introduction}

China's accession to the World Trade Organization (WTO) in 2001 is undoubtedly one of the most important economic changes of the new century. Much has been written about the impact of this event on the economies of China's trading partners (see for example Autor, Dorn and Hanson 2013, Handley and Limao 2013, Pierce and Schott 2015). A few recent papers have focused instead on the effect of China's WTO accession on China itself and have highlighted the significant changes undergone by the Chinese economy (see for example Kee and Tang 2015). The focus of this paper is on one specific aspect of this process of adjustment of the Chinese economy to China's entry into the WTO, i.e. internal migration movements. In particular, we study whether reduced trade uncertainty due to China's accession to the WTO in 2001 triggered changes in internal mobility of Chinese workers. We investigate whether changes in trade policy uncertainty affected demand for local production factors and, in particular, the demand for labor, thus putting pressure on the existing internal migration system.

To answer this question, we implement a difference-in-difference empirical specification based on variation across Chinese prefectures before and after 2001. For our main explanatory variable, we measure trade policy uncertainty using the product-specific normal-traderelations (NTR) gap measure developed by Handley and Limao 2013, and Pierce and Schott 2015. This measure is built by calculating the gap between Most Favorite Nation (MFN) tariffs applied by the United States to Chinese imports and the threat tariffs that would have been implemented if MFN status was not renewed by Congress on a yearly basis (the so called column 2 tariffs of the Smoot-Hawley trade Act). To determine local exposure to uncertainty, we use a weighted average of the NTR gap values for each Chinese prefecture, using information on the prefecture's export basket in 1999 to determine the corresponding weights.

We use data on internal migration rates from the 2000 census and the 2005 mini-census to compile a prefecture-level panel data set. Note that internal migration rates are driven by both supply and demand factors. Supply factors affect migrants' incentives to move and therefore supply migrant labor - according to economic and non-economic incentives. 
Demand factors shape the demand for migrant labor and therefore migration policy. While in most countries citizens are free to move internally, in China, the Chinese Household Registration System - known as the hukou system - has introduced important limits to internal migration. Hukou is a resident permit issued by the Chinese government on a family basis, i.e. newborns inherit hukou location and type from their parents. One of the most important features of the system is that hukou entitles its holder to local social welfare programs, such as public education and public healthcare. For this reason, it limits internal migration since it precludes access to public services to those migrants who cannot acquire a local hukou. Since the late 1990s, hukou policy has been relaxed to facilitate temporary labor mobility as well as to help address urban prefectures' increased demand for labor. Nevertheless, restrictions on long-term migration remain, and policies tend to favor skilled labor.

Taking advantage of the detailed information in the Census data sets, we identify both individuals who have moved from their birthplace and have acquired the hukou of the locality where they currently reside, and those who instead have not. We define the former as "full migrants", and the latter as "partial migrants".

Our analysis delivers several interesting results. First, we show that industries and prefectures facing a larger decline in trade policy uncertainty vis a vis the United States experience a larger increase in exports towards the United States. This evidence suggests that local demand for production factors might be affected by the reduction in trade policy uncertainty. In fact, when we look at labor movements, we find a similar pattern: Chinese prefectures facing a larger decline in trade policy uncertainty experience larger inflows of migrant workers. When we look at different migrant rights entitlements - i.e. whether the migrant has full hukou or not - we find that most of the liberalization has taken the form of "partial liberalization", i.e. it has not involved the attribution of full entitlements to local public goods and services. Moreover, while separately investigating the impact of trade policy uncertainty reduction on skilled and unskilled workers, our results are compatible with the idea that policies have been relaxed more towards skilled workers than towards unskilled workers. In fact, while we find evidence that local demand for unskilled workers has increased also in prefectures facing a larger decline in trade policy uncertainty, the main 
adjustment in the case of unskilled workers has involved an increase in the number of hours worked.

Our paper is related to the growing literature on the regional economic impact of tradeinduced shocks (for example, for poverty and education, see Edmonds, Pavcnik and Topalova 2010, Topalova 2005; for labor market outcomes, see Hasan et. al. 2012, Goldberg and Pavcnik 2005, Kovak 2013 etc.; see Goldberg and Pavcnik 2007 for a review of the literature). These studies typically quantify the size of the shock by using a weighted average of changes in trade policy, with weights based on the industrial or factor endowments distribution in each region within a country, and explore the spatial consequences of the trade policy changes. Most of the studies mentioned above focus on the relaxation of a country's own trade protection (such as a decrease in import tariff rates), and the identification of the causal effect of trade liberalization on the outcome of interest relies on the assumption that such changes in protection are exogenous either in timing or magnitude. This assumption might be satisfied in some specific circumstances, but as the distinguished vast literature on the political economy of trade policy has argued, domestic forces do play an important role in shaping the cross-sectional distribution of trade protection. Compared to this literature, our paper has the advantage of exploiting changes in the trade policy implemented by some of China's main trading partners - rather than China itself. In particular our focus is on the effects of the stabilization of the MFN status, which, in the case of the United States, ensued from China's accession to the WTO in 2001. The size of such a shock is arguably exogenous with respect to the regional economies of China and thus our estimates can be interpreted as the causal effect of trade liberalization.

Two recent papers have investigated the link between trade liberalization and internal labor mobility within China. Tombe and Zhu (2015) develop and calibrate a two-sector, multiple-region general equilibrium model with interregional trade and labor mobility distortions to study the effect of changes in trade and internal migration costs on total factor productivity growth in China around its entry into the WTO. Based on a growth accounting exercise, the authors conclude that about half of the observed total labor productivity growth can be attributed to the decline in trade and migration costs observed in the period. Moreover, the observed more efficient allocation of labor across Chinese prefectures explains 
about twenty percent of total TFP growth. Fan (2015) develops and calibrates instead a multi-factor general equilibrium model to investigate the relationship between changes in trade and internal migration costs and income inequality both between and within regions in China. Lower trade costs increase inequality both across different regions and across different skill groups, with the former playing a role that is twice as big as the latter. At the same time, labor mobility plays an important role in shaping the geography of inequality within China. In particular, skill related differences in mobility costs, by making it comparatively easier for skilled workers than unskilled workers to relocate across prefectures, tend to reduce inequality within coastal areas receiving large inflows of immigrants, while making inequality more severe in the interior regions. The focus of our paper is instead on the impact of trade-induced shocks on policies towards interregional labor mobility within a country. China offers an ideal setting for such an analysis due to the vast variability across Chinese regions both in terms of the availability of human capital and in levels of economic development. Moreover. the growing policy making autonomy enjoyed by Chinese prefectures presents a convincing and rich environment for policy variation, yet still embedded in a larger homogenous economic setting where consistent measures of migration policy are possible.

In addition, our paper is closely related to a few recent studies that focus on the consequences of China's growing involvement in the global economy. Autor, Dorn, and Hanson (2013) analyze the effect of rising Chinese import competition on US local labor markets and find that rising imports cause higher unemployment, lower labor force participation, and reduced wages in local labor markets hosting import competing manufacturing industries. Two recent papers focus instead on China's accession to the WTO as a source of reduction in trade policy uncertainty. In the first contribution, Handley and Limao (2013) develop and calibrate a dynamic general equilibrium model in which policy uncertainty crucially affects the incentives to undertake a costly export investment decision. Their quantitative assessment using U.S. data shows that the reduction in the threat of a trade war explains $22 \%$ of the growth in Chinese export to the U.S. In a related paper, Pierce and Schott 2015 use instead a difference in difference empirical design to examine the link between the sharp drop in U.S. manufacturing employment beginning in 2001 and China's accession to 
the WTO. Interestingly, they find that industries where the threat of tariff hikes declines the most experience larger increases in the value of imports from China and more severe employment losses. At the same time, they do not find a similar effect while considering the European Union, a region for which China's entry in the WTO did not imply a reduction in trade policy uncertainty as MFN status was granted on a permanent basis long before the country joined the WTO. While these recent papers focus on how China's export growth impacts the U.S. economy, our analysis focuses on the direct effect that reduction in trade policy uncertainty had on the Chinese economy.

We briefly outlines the historical contexts of internal labor mobility in China, as well as the trade liberalization in Section 2. Section 3 describes the data, and Section 4 presents the empirical strategy and findings. Section 5 concludes.

\section{Internal Migration and Trade: Background and Context}

\section{$2.1 \quad$ Internal Migration}

Internal migration is of special interest in China because of the household registration (hukou) system, also referred as the household register system. Hukou is a resident permit issued by a prefecture on a family basis; newborns inherit the hukou location and type from their mother. The system was modeled after the Soviet propiska (internal passport system), and had roots also in restrictions to internal mobility applied by imperial China. The People's Republic officially introduced the hukou system in the early 50s to control the movement of citizens between urban and rural areas, and this tool served as part of the "Big Push" industrialization strategy pursued by the early five-year plans. The goal was to set up a two-tier system: an industrial sector, based in the cities, as the core for the big push; and an agricultural sector, as the source of cheap raw materials.

An individual was broadly categorized as a "rural" or "urban" worker. A worker seeking to move from the rural to urban areas to take up non-agricultural employment would have to apply through the relevant bureaucracies. The number of workers allowed to make such moves was tightly controlled by the central government. As a result of the system, migrant workers would require up to six passes to work in provinces other than their own. People 
who worked outside their authorized domain or geographical area would not qualify for grain rations, employer-provided housing, or healthcare. There were also controls over education, employment, marriage and so on. All these measures resulted in very significant restrictions on internal migration.

There are two hukou types (leibie). Individuals were broadly categorized as a "rural" or "urban" residents. In the early period of the system $(60 \mathrm{~s}-80 \mathrm{~s})$, the "urban" (nonagricultural) hukou entitled the holder to a wide array of state provided services: housing, employment, grain rations, education and medical care. At the same time, the "rural" (agricultural hukou) population was expected to be mainly self sufficient, receiving very limited, if any, state transfers.

The place of hukou registration (suozaidi) defines individual rights for services in a specific locality. While the hukou type (leibie) defined the type of services and welfare available to individuals (typically set by the central government), the hukou suozaidi defined where individuals would receive these services. As a result, cities and towns have both agricultural and non-agricultural population living in them. Specifically, excluding foreign nationals, in any city there were four types of people, based on hukou status:

- Those who hold local non-agricultural hukou

- Those holding local agricultural hukou

- Those holding non-local, non-agricultural hukou

- Those holding non-local, agricultural hukou

Prior to the late 1990's, any official permanent migration involving a change in entitlement status and/or a change in residential place required approval by the central government. Typically such approval rates were limited to 0.15-0.2 percent of the non-agricultural population. The central government bore the main fiscal responsibility for increases in non-agricultural hukou population.

Until 1978 the enforcement of the system was strict. Almost all residents remained in their de jure residence. In the early 80s, individuals not living in their de jure residence amounted only to $0.6 \%$ of the total population (Chan 2009). After the introduction of the 
reforms, demand for unskilled labor in the rapidly growing industries in the cities started to pick up, and the extent to which the hukou system is enforced has declined drastically. There has also been recognition that the system is an impediment to economic development. State Council directives were issued in 1992 and 1998 to start allowing city authorities the power to grant local hukou to selected groups of individuals, who were typically investors and highly educated workers with a place of residence in the city. The reform allowed also the elimination of the distinction between agricultural and non-agricultural hukou, even though the take up rate varied and only a few provincial administrative units (e.g. Guangdong, Zhejiang, Shanghai, Hebei, Henan and Jiangsu) announced in the early 2000 that they would eliminate this distinction within some towns/county level cities. China's accession to the World Trade Organization (WTO) has further pushed reformation to the hukou system in order to liberate movement of labor for the benefit of the economy. As a result, since the 1990s, China has witnessed large labor migration.

\subsection{Trade Liberalization}

China became a member of the WTO in December 2001 after several years of intense negotiations. The trade liberalization studied in this paper, namely the US granting China permanent normal trade relations at the end of 2000, took place concurrently and was closely related to China's WTO accession. EU granted China permanent MFN status in 1980; at the same time, US granted China MFN status subject to yearly renewal. It was a contentious political process which created substantial uncertainty in the tariff rates Chinese exporters faced in the US market. ${ }^{1}$ In fact, in the 1990s, a bill was put before Congress every year to revoke MFN status to China. If enacted, these bills would have led to the application of the Smooth Hawley tariff. In 2000, the average MFN tariff was 4\%, whereas if China had lost MFN status, it would have faced a 31\% average tariff. While China's normal trade relations with the US had never been revoked, and Chinese imports had enjoyed MFN tariff rates in the US between 1980 and 2000, the uncertainty imposed by China's conditional MFN status with the US was not trivial. The reduction of this uncertainty at the end of 2000, as the US granted China permanent MFN status had a significant impact on the US

\footnotetext{
${ }^{1}$ For a more detailed description, see Handley and Limao 2013 and Pierce and Schott 2015.
} 
economy, as it has been pointed out in several recent papers (Autor, Dorn and Hanson 2013, Handley and Limao 2013, Pierce and Schott 2015). More precisely, there is evidence that China's entry had a substantial effect on subsequent employment growth in the US manufacturing sector, and that this effect varied with the extent to which tariff uncertainty was affected by China's entry in the WTO. In particular, Pierce and Schott (2015) find that China's entry in the WTO led to a 3-4 percentage points decline in employment growth in US manufacturing in the short run, and to a 12-16 percentage points decline in the medium run. Autor, Dorn and Hanson (2013) finds that import competition explains one-quarter of the contemporaneous aggregate decline in US manufacturing employment.

\section{$3 \quad$ Data and Descriptive Statistics}

To carry out our analysis, we have combined data from a variety of different sources. In particular, we have used individual level information from the population census to construct measures of internal migration, and transaction level trade data to construct our measure of exports and imports. This detailed micro-data have then been aggregated to construct a prefecture-level panel dataset. To capture the overall trade policy stance, we have used tariff data from the World Integrated Trading System database, combining it with information on trade policy uncertainty vis a vis the United States, the pervasiveness

of barriers to investment, the incidence of the U.S. Multi Fiber Agreement (MFA) quota and the availability of production subsidies for Chinese firms.

The remainder of this section outlines the main steps we have followed to construct our dependent variable and our key explanatory variables. The Data Appendix contains more detailed information on the data sources.

\subsection{Migration Measures}

Prior to defining the relevant migration measures used in this paper, it is important to have a clear understanding of the organization of local government structures in China. Several levels exist, and starting from the highest to the lowest, we can distinguish the provincial level, the prefecture level, and the county level. There are 31 provincial level 
units, including 27 provinces and 4 provincial-level municipalities ${ }^{2}$. Each province can be additionally subdivided into prefectures. Each prefecture has a leading prefecture-level city (PLC), i.e. a municipality that is given prefecture status and the right to govern surrounding counties. Each PLC, with its subordinate counties, forms a prefecture. Excluding the 4 provincial municipalities mentioned above, there are 333 prefecture-level units in China.

To eliminate confusion, we use "prefecture" to refer to a prefecture-level division consisting of the governing prefecture-level city (PLC) and the counties that belong to the prefecture, "PLC" to refer to prefecture-level city that bears the same name as the prefecture $^{3}$, and "county" to refer to any county or county-level city.

The tree graph below summarizes the administrative division of a province. Every province has several prefectures. Each prefecture has its own prefecture-level city (PLC) and a few counties that are governed by the PLC. A PLC mainly consists of districts that are urban areas. ${ }^{4}$ Each county consists of "subdistricts" (urban) and "towns" (urban or rural). Furthermore, subdistricts have "communities" (urban), and towns have communities (urban) and villages (rural). ${ }^{5}$

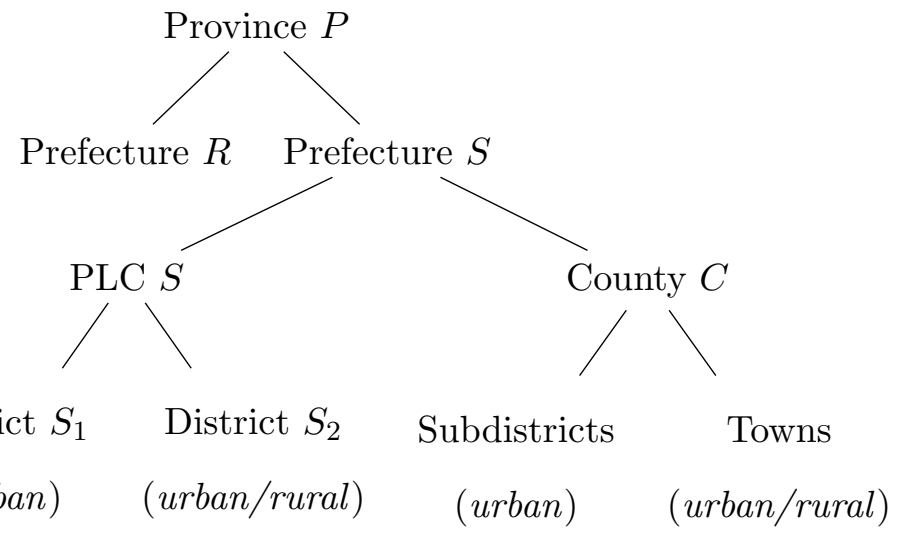

The hukou system mandates that all citizens of China are registered at a certain location. In practice, this means that the hukou record of each person indicates a specific address, detailed to street level and makes up this person's registration location. For example, a

\footnotetext{
${ }^{2}$ The latter are the four large cities of Beijing, Tianjin, Shanghai, and Chongqing. A provincial-level municipality is the same administrative unit as a province, but since it is essentially a broadened concept of "city", or an expanded metropolitan area, it has the same structure as a prefecture. Thus we treat them as prefectures in our analysis.

${ }^{3}$ For example, the governing PLC of the Nanjing Prefecture is Nanjing City.

${ }^{4}$ Some PLCs also have "towns" that are mixed with urban and rural areas. Not all PLCs have "towns".

${ }^{5}$ Again, not all subdistricts are urban, and not all towns have both rural and urban areas.
} 
person's hukou registration place can be "No. 100 City Rd., Apt 222, Oldtown District, Nanjing City, Jiangsu Province, China". Since the registration record is meant to keep track of where everyone is, and is detailed to street numbers, even moving from one apartment to another within a county requires altering one's registration record. However, changing hukou location within a county is much easier than changing it across counties. Our analysis of internal migration in this paper hinges on residents' hukou information as reported in the census data. As a result, a clear definition of migration is required. For the purpose of our analysis, our working assumption is that migration policies are set at the prefecturelevel. Moreover, we focus on cross-county migration and ignore within-county moves - as within-county migration is unencumbered. As a result, in our study an internal migrant is an individual who moves across counties. Depending on whether an internal migrant gains or not residence in the destination city, we will distinguish between full migrants and partial migrants. More precisely,

1. A "partial" migrant is an individual who lives in a county without the local hukou. He can be identified from the Census data using information under "Registration Type"; anyone, in any location, whose registration type appears to be "registered elsewhere", is a partial immigrant in his current location.

2. A "full" migrant is an individual who has relocated to a different county and changed his hukou registration to his current residence. Since information on individual migration history is not available in the Chinese population census, the identification of full migrants requires a set of plausible assumptions. In particular, we can only observe current hukou registration place and type, and only where people lived previously, but not where their hukou was registered previously. As a result, full migrants are local residents whose previous residence ${ }^{6}$ is located elsewhere. Note that we can further distinguish within-province full migration and cross-province full migration. Withinprovince full migration happens as people move within a province, and change their hukou to another county in the same province. Cross-province full migration occurs if the migrant crosses the provincial border.

\footnotetext{
${ }^{6}$ Note that we use residence five years ago, an information which is consistently collected across census waves.
} 
Based on whether an individual has completed at least a high school degree or not, we will also distinguish between high skilled and low skilled immigrants. To better illustrate the two definitions of migration, graph 1 and graph 2 show the composition of people surveyed at a certain county $\mathrm{A}$, belonged to prefecture $\mathrm{R}$, which is located in province $\mathrm{P}$.

Table 1 reports summary statistics on the internal migration in China between 19952000, and 2000-2005. Between 1995 and 2000 approximately 32 million employed individuals changed their province of residence. Migration in this period is gender biased, as about 56 percent of the migrants are males, and 44 percent are females. Five year mobility rates hover around 4.6 percent, a figure that is significantly lower than in the United States (Molloy, Smith, and Wozniak 2011) in the same period. Interestingly, mobility increased substantially over the following five years, when approximately 41 million employed individuals changed province of residence - compatible with a relaxation in the overall restrictiveness of the migration policy stance. The gender bias appears to be stable, while the five year mobility rate has increased to approximately 6 percent. Turning to the breakdown of migrants by skill level, the last two rows of the top panel indicate that between 1995 and 2000 there was no clear skill bias: while among men we observe slightly more skilled migrants, the opposite is true for females. When we consider instead migration between 2000 and 2005 (last two rows of the bottom panel), we can clearly note a bias towards the more highly skilled. In fact, both skilled males and females are approximately one percentage point more likely to relocate across provinces than their unskilled counterparts.

Figures $1-4$ illustrate the geographic distribution of recent cross-province partial and total (partial and full) migrants, as a share of the destination's population in 2000 and 2005. Several interesting patterns emerge. First, the coastal prefectures of South-Eastern China are major destinations of migration flows. Among these destinations, two major economic zones (Yangtze River Delta region, and Pearl River Delta region) have the highest migration rates. In particular, very high internal migration flows are observed for instance in the prefectures surrounding Hangzhou Bay in the Yangtze River Delta region. In 2005, Shanghai had total migration rate of $35.20 \%$, Hangzhou and Ningbo had total migration rate of $20.20 \%$ and $37.61 \%$, respectively. Prefectures in the Pearl River Delta region also have high migration rates. In 2000, Dongguan's total migration rate was 80.37\%, Guangzhou's 
and Shenzhen's were $36.78 \%$ and $81.03 \%$, respectively. Second, migration flows are high also in several prefectures in the North East and in a few prefectures in the West ${ }^{7}$. Beijing and Tianjin are major migration destination in the Bohai Bay Region and so are a few prefectures in the three Northeastern Provinces (Heilongjiang, Jilin and Liaoning), such as Dalian (13.52\% of the total population were made by recent immigrants in 2005) and Daqing (8.15\%). Third, central China does not appear to be a major migrant destination, with the exception of a few urban prefectures, such as Chengdu in Sichuan province $(10.44 \%$ in 2005) and Xi'an in Shaanxi province (13.04\% in 2005). Comparing migration patterns over time, we can see some interesting changes. For instance, new inflows increased in the South Eastern part of the country, and in particular several additional prefectures became destinations of large new immigrant arrivals. The total migration rate in Huainan (Anhui province) increased from $4.77 \%$ in 2000 to $14.90 \%$ in 2005, and that of Zhoushan (Zhejiang province) from $5.42 \%$ in 2000 to $16.45 \%$ in 2005 . The same holds true also for several prefectures in the North East of the country. For example, Tianjin's total migration rate increased from $7.63 \%$ in 2000 to $14.78 \%$ in 2005, and that of Shenyang (Liaoning province) from $6 \%$ in 2000 to $11.05 \%$ in 2005 .

\footnotetext{
${ }^{7}$ The high migration prefectures in the Northwest are mainly oil-producing desert cities (Fan 2015) and prefecture-level jurisdictions in Xinjiang Production and Construction Corps.
} 
1. Composition of survey subjects in 2000 Census:

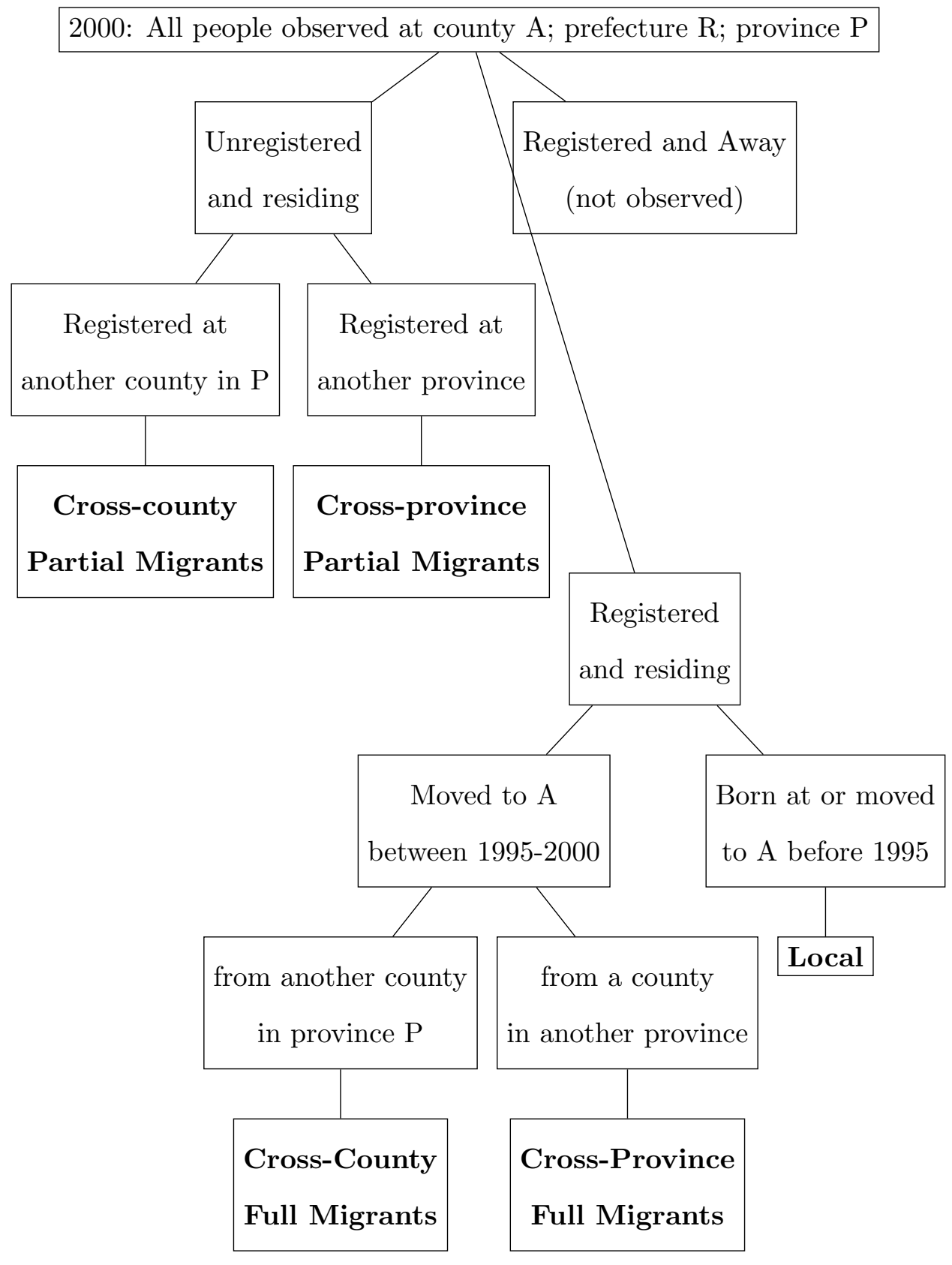


2. Composition of survey subjects in 2005 Census:

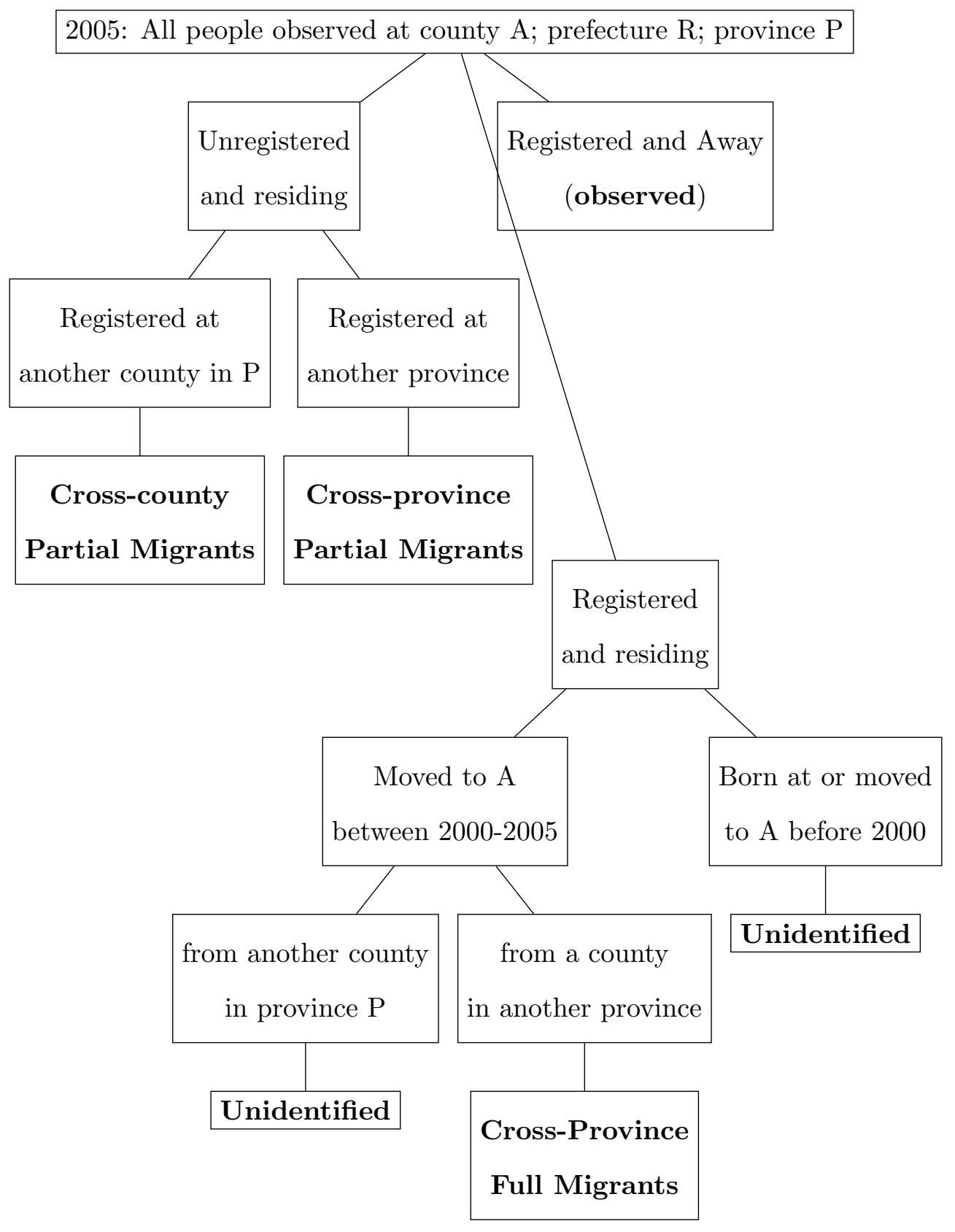

\section{$3.2 \quad$ NTR gap}

Our key explanatory variable captures the reduction in the trade policy uncertainty vis a vis the United States faced by Chinese exporters as a result of China's entry in the WTO. Following Pierce and Schott (2015) we measure it using the Normal Trade Relations (NTR) gap. The latter is defined as the difference between the Normal Trade Relations (NTR) 
tariffs, reserved to WTO members and applied to China's exports to the US since the early eighties, and the non-NTR rate, which is instead the higher tariff rate assigned to nonmarket economies and originally established under the Smoot-Hawley tariff introduced in 1930. The latter would have been applied to China if congress failed to extent MFN status to China in any year before China's entry in the WTO. More precisely, the NTR gap for product type $i$ is defined as:

$$
\text { NTRgap }_{i}=\text { nonNTRrate }_{i}-\text { NTRrate }_{i}
$$

Table 2 summarizes product level NTR gaps, distinguishing also between skilled labor intensive and unskilled labor intensive goods. ${ }^{8}$ As it is immediately clear, the average NTR gap was substantial, at over 30 percentage points. Furthermore, it was higher for unskilled labor intensive goods (35 percentage points) than for skilled labor intensive goods (27 percentage points). Figure 5 illustrates the distribution of NTR gaps across product types in 1999, and shows substantial variation. For example, "Optical fibre cables" (product 854470 ) are characterized by an NTR gap of $65 \%$, whereas "Other woven fabrics of silk" (product 500720) exhibit an NTR gap of 90\%. At the same time, "Ginseng roots" (product 121120) is among the 448 products for which China's entry in the WTO did not have an impact, i.e. it is characterized by a 0 NTR gap.

To carry out our empirical analysis, we have aggregated our product level NTR gap measure at the prefecture-level using as weights the export basket of each Chinese prefecture, as observed in over the period 1997-1999, i.e. before China's accession to the WTO. As a result, the NTR gap in prefecture $j$ is defined as:

$$
N T R g a p_{j}=\sum_{i} \frac{\operatorname{Exp}_{i j}}{\operatorname{Exp}_{j}} * N T R g a p_{i}
$$

where $E x p_{i j}$ are the exports of good $i$ from prefecture $j$ and $E x p_{j}$ are total exports of the prefecture. Table 3 reports the summary statistics for several alternative measures which will be used in our empirical analysis. In the first column, we display prefecture level aggregates built using information from the prefecture export basket towards the entire

\footnotetext{
${ }^{8}$ Skilled labor intensive goods are those characterized by a higher than average skill intensity.
} 
world; in the second we instead use information from the export basket towards the United States. In the first three rows we report alternative NTR gap measures (for all products, for skilled labor intensive products and for unskilled labor intensive products) calculated using the share of each product in the total exports of the prefecture by value as weights. In the last three rows we display instead analogous unweighted measures.

Comparing the first and the second column, we can immediately see that focusing on the export basket vis a vis the world or the one vis a vis the United States does not significantly change our measure of trade policy uncertainty, with the only important exception being skilled labor intensive goods, where using exports towards the United States leads to a 3 percentage points higher weighted NTR gap, and a 1.2 higher unweighted NTR gap. Moreover, as we had already seen in Table 2 while considering product level information, our prefecture level NTR gap measures are higher for skilled than for unskilled goods. Finally, it is worth noting that our weighted NTR gap measures appear to be systematically lower than our unweighted ones.

Figure 6 offers a snapshot of the NTR gap by prefecture in 1999, constructed using exports to the U.S. as weights. As it can be immediately seen, NTR gaps are higher in the South-Eastern coastal region (Shaoxing in Zhejiang province has NTR gap of $49.4 \%$, and Chaozhou in Guangdong province has NTR gap of 47.3\%), but several prefectures in Central China do also exhibit very high NTR gaps (for example, Nanchong and Neijiang located in Sichuan province have NTR gaps of $44 \%$ and $50 \%$, respectively).

\subsection{Other controls}

Table 4 reports descriptive statistics for the variables used in the main analysis. The dependent variable and the main explanatory variables have been already described in detail in the previous sections, so our focus here is on the additional controls used in our analysis. Additional controls used in our analysis include tariff abroad, import tariff, production subsidy, barriers to investment, and MFA quota restrictions. We aggregate these measures from product/industry/firm level to the prefecture level, and they are described below.

China is a major destination of foreign direct investment, and several studies have emphasized the role that FDI has had in promoting local development (Chen, Chang, and 
Zhang (1995)). We proxy barriers to investment using the Contract Intensity measure proposed by Nunn (2007). The latter describes the share of intermediate inputs used by a firm that require relationship-specific investments by the supplier. The higher is the contract intensity of a firm, the more pervasive is the effect of the presence of investment barriers in a prefecture. Upon China's accession to WTO, barriers to investment were eliminated, and as a result prefectures characterized by firms with higher contract intensity disproportionately benefited from trade liberalization. Our measure of contract intensity is constructed in a similar way as NTR gaps and captures the reduction in investment barriers due to China's WTO accession.

Factor demand are likely to be affected by the overall trade policy environment. To quantify the effect of trade restrictions faced by Chinese exports abroad, we have built a measure of Tariff Abroad, which is constructed as the weighted average tariff rate faced by a prefecture in export markets, where the weights are represented by the prefecture's export basket in 1997-1999. To assess the impact of the domestic trade policy stance, we have constructed a measure of Import tariff, defined as the weighted average tariff rate applied on a prefecture' import basket. An additional sectoral driver that played an important role in this period is represented by the MFA Quota Bound, measuring U.S. apparel and textile quotas under the Multi Fibre Agreement (MFA) and the Agreement on Textiles and Clothing (ACT). This information is taken from Brambilla, Khandelwal and Schott 2010. We use MFA Quota Bound to measure the relaxation of MFA quotas; specifically, we calculate the share of export that faced binding MFA quota ${ }^{9}$. Constructed similarly as a treatment of trade liberalization, MFA Quota Bound measures the share of textile export that would have faced binding MFA quota were not for China's WTO-accession. Last but not least, several Chinese exporters benefit from a series of government subsidies 10. Information on them is taken from China's Annual Survey of Industrial Firms (CASIF).

\footnotetext{
${ }^{9}$ We consider products with fill rate (share of actual import in allowed import) higher than $85 \%$ as products with binding quota.

${ }^{10}$ Defever and Riaño (2012) document that until 2008, foreign-owned firms in China that exported over $70 \%$ of their production enjoyed a $50 \%$ reduction in the corporate income tax rate. By locating in one of the numerous special economic zones, firms could benefit from an even lower tax rate. Additional benefits included VAT rebates and lower tariffs on imported machinery and intermediate inputs, direct cash subsidies, discounted utility and land rental rates and easier access to finance. Defever and Riaño (2012) find that as a direct consequence of these subsidies, over a third of Chinese manufacturing exporters sell more than $90 \%$ of their produce abroad.
} 
The variable Production Subsidy measures the share of local production which is subsidized.

\section{Empirical Analysis}

\subsection{Empirical Specification}

We are interested in the impact on a prefecture's immigrant inflows of the trade barriers a prefecture faces. Specifically, the question we ask is: did prefectures with bigger NTR gaps (and thus bigger uncertainty reduction in tariff rates due to WTO accession) experience larger immigrant inflows after China's WTO accession, compared to prefectures with smaller NTR gaps? To answer it, we carry out a difference-in-difference estimation strategy. The first difference exploits variation over time, that is, pre- and post-WTO accession, as China's WTO accession provides variation (reduction) in NTR gaps over time. In addition, Chinese prefectures differ in their exposure to tariff uncertainty reduction according to the composition of their trade baskets prior to China's WTO accession. Thus the second difference we exploit is cross-sectional, specifically between the high NTR-gap prefectures (more intensively treated) and the low-NTR gap prefectures (less intensively treated). Besides NTR gaps, we also consider other measures of trade barriers, in particular tariff rates and non-tariff barriers. The prefecture-level panel data set described in the data section provides the variation used to identify the effects of WTO accession, and our baseline specification is given by:

$M_{j t}=\alpha+\beta_{1} \cdot \mathbf{1}\left\{\right.$ post $\left._{t}\right\} \cdot \mathrm{NTR} \mathrm{Gap}{ }_{j}+\beta_{2} \cdot \mathbf{1}\left\{\right.$ post $\left._{t}\right\} \cdot \mathrm{WTO}_{j}+\beta_{3} \cdot \mathbf{1}\left\{\right.$ post $\left._{t}\right\} \cdot \Delta \operatorname{Tariff}_{j}+\gamma \cdot X_{j t}+\delta_{t}+\delta_{j}+\epsilon_{j t}$

where $M_{j t}$ is our measure of immigrant inflows, specifically the share of immigrants in city $j$ at year $t(t=\{2000,2005\})$. NTR $\operatorname{Gap}_{j}$ measures the time-invariant uncertainty in trade barriers with the US faced by each prefecture before WTO accession, and $\mathrm{WTO}_{j}$ includes non-tariff barriers (MFA quota and investment barriers) which were relaxed as China acceded to WTO. Finally, $\Delta$ Tariff $_{j}$ is the change in import tariffs and tariffs faced by Chinese exporters abroad between 2000 and 2005. These variables are constructed as 
described in Section 3. The trade barriers were relaxed as China entered the WTO, so NTR $\mathrm{Gap}_{j}, \mathrm{WTO}_{j}$, and $\Delta$ Tariff $_{j}$ are interacted with the time dummy post ${ }_{t}$ to capture the reduction in these trade barriers.

We use time fixed effect, $\delta_{t}$, to control for the changes in migrant inflows common across all prefectures between 2000 and 2005. Thus the coefficients on trade barrier reductions do not capture any aggregate effects of China's WTO accession. We also control for time-invariant prefecture characteristics with a set of prefecture fixed effects denoted as $\delta_{j}$. Finally, $X_{j t}$ is our measure of production subsidies.

Note that the prefecture-level trade barriers are constructed using prefecture-specific trade baskets prior to the WTO accession. Thus, the question we ask by estimating specification 1 is the following: how would immigrant inflows to each prefecture change if trade patterns of each prefecture remained constant and the only change was in trade barriers reductions? In other words, the specification is trying to isolate the impact of the reduction in trade barriers, independently from any change in trade baskets which might have occurred. Thus, the key identifying assumption is that, conditional on the common time trend and prefecture fixed effects, pre-WTO local trade baskets did not respond to changes in immigrant inflows in anticipation of the trade liberalization to come.

$\beta_{1}$, the coefficient on NTR gaps, is our main coefficient of interest. Everything else equal, a positive value on $\beta_{1}$ in Equation (1) would suggest that the reduction in uncertainty on the U.S. tariff rates is associated with an increase in immigrant inflows relative to the common time trend. Similarly for $\beta_{2}$ and $\beta_{3}$, a positive value would suggest that the reduction in tariff and non-tariff barriers is associated with higher immigrant inflows.

As explained in Section 3, NTR gaps are measured as the difference between U.S. nonNTR tariff rates (i.e. Smoot-Hawley tariff rates) and U.S. NTR tariff rates (i.e. MFN tariff rates). As a consequence, since NTR gaps are a function of U.S. trade policy, and in particular both past and present U.S. policy, they are not vulnerable to endogeneity concerns. In particular, it is safe to assume that current Chinese political-economy drivers could not have affected Smoot-Hawley U.S. tariff rates, which were set by the U.S. Congress in the 1930's. In addition, U.S. MFN tariff rates are the result of U.S. multilateral negotiations with all WTO countries, therefore they are unlikely to have been impacted by local conditions in 
China, especially given that China was not part of the WTO at the time when the MFN rates we use were set by the U.S.. The same type of argument makes us confident that the exclusion restriction for changes in tariffs abroad is satisfied.

Stronger but plausible assumptions are required to justify the exclusion restriction for changes in Chinese import tariffs. In this case, one important concern is that unobserved prefecture-specific time varying shocks might at the same time affect immigrant inflows and be correlated with changes in Chinese import tariffs over time. Note however that we measure the latter changes with the interaction of changes in national-level tariffs with initial prefecture-specific trade composition, making this concern less severe.

\subsection{The impact on exports to the U.S.}

Our main analysis focuses on the effect of the trade liberalization experienced by China around the time of WTO accession and changes in internal migrant flows at the prefecture level. Clearly, one channel through which this relationship can operate is through exports. If Chinese exports are affected by trade liberalization, this is likely to impact the local demand for production factors, and this could be an important driver of internal factor mobility.

To assess the impact of a reduction in trade policy uncertainty, we estimate a specification which is very similar to the one presented in the previous section, the only difference being that we focus on Chinese exports as the dependent variable (see Table 5). We consider variation both across product codes (columns (1)-(3)) and across prefectures (columns (4)-(6)). Data on exports are available at higher frequency than data for internal immigrant inflows. Therefore, in these regressions we exploit variation for a higher number of years around the time of the WTO accession. In particular, we use data from 1997, 1998, and 1999 as pre-treatment periods, and 2002, 2003, and 2004 as post-treatment periods. ${ }^{11}$

We start with a parsimonious specification (columns 1 and 4)), in which we control

\footnotetext{
${ }^{11}$ Instead of using tariff changes from 2000 to 2005 as trade liberalization as in the main specifications, we use each year's level of tariff and non-tariff barriers to measure trade barriers, and explore their effect on exports over time. The interpretation on $\beta_{1}$, the coefficient on NTR gaps, and $\beta_{2}$, the coefficient on reduction in non-tariff barriers, are the same to the main specification. Everything else equal, a positive value on $\beta_{1}$ and $\beta_{2}$ would suggest that the reduction in uncertainty of U.S. tariff rates is associated with increases in exports to the U.S. from China, relative to the common time trend. For $\beta_{3}$, a negative value would suggest that the lower tariff rates are associated with higher export volumes to the US.
} 
only for the change in trade policy uncertainty, while in the second specification (columns 2 and 4) we account also for changes in investment barriers, and in the third specification (columns 3 and 6 ) we present a more complete specification in which we account for the tariff levels, both applied to Chinese exports and on imports to China. Our results indicate that the reduction in trade uncertainty brought about by Chinas WTO accession had a positive impact on exports to the U.S. both at the product and at the prefecture level. At the same time, interestingly, the other trade barriers variables do not appear to have a significant impact (with the exception of the negative impact of U.S. tariffs in the product level regressions).

\subsection{The impact on internal migration}

We turn next to examine the impact of trade liberalization on internal migration flows. Our results are presented in Table 6 and Table 7.

Table 6 shows the baseline OLS difference-in-difference (DID) results using, as dependent variable, the share of all employed migrants (both partial and full, and both across and within provinces) out of the locally employed workers. The presentation follows the same structure as in Table 5. Regression (1) focuses only on the impact of prefectures uncertainty reduction while regression (2) adds also the reduction of investment barriers. Finally, regression (3) presents the full specification where reductions in tariff rates and other non-tariff barriers are also accounted for. All specifications include prefecture and time fixed effects, and robust standard errors are reported in parentheses. All estimates suggest that a larger reduction in uncertainty is associated with an increase in the share of immigrant in the population (relative to the common time trend). Everything else equal, each percentage point reduction in tariff uncertainty with the U.S., as measured by NTR gap, is associated with 0.043 percentage point increase in the migration rates of full plus partial migrants. With the prefecture level NTR gap averaging at $27 \%$, the estimates of $\beta_{1}$ translate into a 1.16 percentage point increase in the migration rate relative to the national baseline. It is worth noting that reductions in tariffs abroad also have a positive although insignificant impact on migration rates: That is, the larger the reduction in tariff rates faced abroad by exporters of a Chinese prefecture, the higher the increase in immigrant rates to 
this prefecture. This is consistent with the fact that international prices of exported goods are likely to increase when tariff rates abroad decrease (terms-of-trade effect of tariff reductions); moreover, prefectures demand more immigrant labor as international prices of exported goods increase, since production also goes up. Since we constructed trade barriers using pre-WTO accession trade baskets, the compositional changes in import/export structure is controlled for. Thus, in our regressions trade liberalization increases migrant inflows by raising the demand for labor through product price changes only. On the other hand, the negative (but insignificant) sign on import tariff reduction suggests that, the larger the reductions in a prefectures import tariff rates, the smaller the increase in immigrant rates to that prefecture. This suggests that prefectures might replace immigrant labor with cheaper imported inputs.

In Table 7 we study instead whether the reduction in trade policy uncertainty had a differential effect, depending on the type of migrants considered. We focus on migration across provinces - as data for full migration are available only at this level. As a benchmark, columns (1)-(3) reproduce the same results of Table 6 and present the estimated impact of trade liberalization on total cross province migrants (partial plus full); columns (4)-(6) focus instead on partial migrants, and Columns (7)-(9) on full migrants. Our results for cross-province full and partial migration are broadly comparable to the findings in Table 6 , At the same time, we do not find much evidence of a significant impact of the reduction in trade policy uncertainty on full migration, and this result indicates that the liberalization of migration policy in Chinese prefecture did not involve full entitlement to the public goods and services associated to the acquisition of the local hukou status.

To better understand how Chinese local labor markets adjust to the trade shock, we carry out a series of additional exercises, which are reported in Table 8. Our point of departure is that, in addition to hiring immigrants, local labor markets can accommodate increased demand in other ways such as by employing more native workers, or by extending the number of working hours of the employed workers. To explore the role of these two mechanisms, in columns (1)-(3) we study the effect of a reduction in trade policy uncertainty on the employment rate, whereas in columns (4)-(6) we focus on weekly working hours of all employed workers. Our results indicate that the local labor market adjustment took 
mainly place through changes in the number of hours worked.

\subsection{Robustness}

We explore the robustness of our basic results in two ways. First, we use alternative definitions of our measures of trade barriers. Second, we carry out a series of placebo tests to assess the plausibility of our difference in difference estimation strategy.

In our benchmark estimates we have used a measure of the weighted NTR gap at the prefecture level, where the weights have been calculated using that prefecture's export basket with the United States in 1997-1999. One possible concern is that these might be endogenous since prefectures can respond to trade barriers by adjusting how much they import and export. Thus the prefecture-level NTR gaps weighted using trade volumes might well understate the policy uncertainty prefectures face. We address this concern in three ways. First, we use an alternative NTR gap measure built using the trade basket associated with the entire world, rather than the United States (see columns (1)-(3) of Table 9). Second, we use an unweighted measure of the NTR gap based on the export basket with the United States (see columns (4)-(6)) and third, we use an unweighted measure based on the export basket vis a vis the entire world (see columns (7)-(9)). Our basic results are unaffected, indicating that the possible endogeneity of trade shares with the United States is not a major concern.

Our basic identification strategy relies on a difference in difference methodology. For our estimates to be plausible, we need to rule out the presence of any difference in time trends in the pre-treatment period between the treatment and control group. To this end, we estimate our model using a placebo treatment. This involves re-estimating the difference-indifferences model over the pre-treatment period, but with the assumption that the treatment took effect at an earlier date. Since this treatment precedes the introduction of the policy change we have been studying investigated, the difference-in-difference estimator should be statistically insignificant and close to zero.

Our placebo analysis is based on using migrant inflows that took place between 1990 and 2000, and determine whether they were affected by the subsequent reduction in trade policy uncertainty. The results are reported in Table 10 and Table 11. As both these tables 
show, the reduction in trade barriers that took place when China joined the WTO had no impact on internal migration inflows prior to 2000 .

\section{$5 \quad$ Skill-Specific Analysis}

Much of the policy debate around immigration policy today involves a comparison between the benefits and the costs of skilled immigration compared to unskilled immigration. In this section, we extend our analysis of internal migration within China, by exploring the possible presence of heterogeneous effects based on skill. As we have already discussed in section 3 for the purpose of our analysis a skilled worker is an individual who has completed at least a high school degree, whereas someone with less than a high school education will be considered unskilled.

Using the skill intensity of each product, we separate each prefecture's trade basket into a skilled-labor-intensive sector and an unskilled-labor-intensive sector. Using the same specification as our basic findings (Equation 1), Table 12 reports estimates of the impact of a reduction in trade policy uncertainty on total migration rates of unskilled (Columns (1)-(3)) and skilled workers (Columns (4)-(6)), using the same measure of trade barriers for both skill groups. Our results indicate that a reduction in trade policy uncertainty has a strong and significant impact on skilled migration rates, but no effect instead on unskilled migration rates. We can think of two possible explanations for this finding. First, the increase in demand for labor is bigger for skilled workers. Second, given the same increase in labor demand for both skill groups, skilled labor is more mobile. We further explore the role played by these two mechanisms by looking at the labor market outcomes of these two groups. Table 13 and Table 14 report respectively specifications with weekly working hours and employment rate for the skill groups as dependent variables.

As we can see, employment rates for both groups are not affected by the reduction in trade policy uncertainty, whereas the latter has a positive impact on weekly working hours for unskilled workers, but not for skilled workers. These results suggest that skilled labor is more mobile; that is, a reduction in trade policy uncertainty led to an increase in demand for both skilled and unskilled labor, but the unskilled labor market adjusted by seeing the 
number of working hours increasing, whereas the labor market for skilled labor reacted by employing more migrants.

Last, we have built a fully skill-specific prefecture panel data, matching skilled (unskilled) labor with the weighted trade barrier measures using skilled (unskilled)-laborintensive basket as weights. By doing so, we can assess how labor demand for each skill group was affected by the corresponding sector's trade liberalization. Table 15 reports our estimates, which follow the same pattern as in Table 12.

\section{Conclusion}

In this paper we have carried out a systematic analysis of the effects of China's entrance in the WTO on the internal mobility of Chinese workers. Building on the recent work by Pierce and Schott (2015) and Handley and Limao (2013), we have focused on the role played by the reduction in trade policy uncertainty. We have uncovered several interesting results. First, we have shown that industries and prefectures facing a larger decline in trade policy uncertainty vis a vis the United States experience a larger increase in exports towards that country. This evidence is consistent with the idea that local demand for production factors might be affected by this policy change. In fact, when we looked at labor movements, we have uncovered similar patterns: Chinese prefectures facing a larger decline in trade policy uncertainty experience larger inflows of migrant workers, which under our assumption that migration policies have been binding throughout the period, is equivalent to a greater decrease in restrictions to mobility. When we look at different migrant rights entitlements - i.e. whether the migrant has full hukou or not - we find that most of the liberalization has taken the form of "partial liberalization", i.e. it has not involved the attribution of full entitlements to local public goods and services. Moreover, while investigating the impact of trade policy uncertainty reduction separately on skilled and unskilled workers, our results are compatible with the idea that policies have been relaxed more towards skilled workers, than towards uskilled workers. In fact, on the one hand we have found that the increased demand for skilled workers has led to an increase in the employment of immigrant workers. On the other, while we find evidence that the local demand for unskilled workers has 
increased also in prefectures facing a larger decline in trade policy uncertainty, the main adjustment in this segment of the labor market has involved instead an increase in the number of hours worked.

\section{References}

Autor, D. H., D. Dorn, and G. H. Hanson (2013). The China syndrome: Local labor market effects of import competition in the United States. The American Economic Review 103(6), 2121-2168.

Benhabib, J. (1996). On the political economy of immigration. European Economic Review $40(9), 1737-1743$.

Brambilla, I., A. K. Khandelwal, and P. K. Schott (2010). China's experience under the multi-fiber arrangement (mfa) and the agreement on textiles and clothing (atc). In China's Growing Role in World Trade, pp. 345-387. University of Chicago Press.

Chen, C., L. Chang, and Y. Zhang (1995). The role of foreign direct investment in china's post-1978 economic development. World development 23(4), 691-703.

Defever, F. and A. Riaño (2012). China's pure exporter subsidies.

Facchini, G., A. M. Mayda, and P. Mishra (2011). Do interest groups affect us immigration policy? Journal of International Economics 85(1), 114-128.

Facchini, G. and G. Willmann (2005). The political economy of international factor mobility. Journal of International Economics 67(1), 201-219.

Fan, J. (2015). Internal geography, labor mobility, and the distributional impacts of trade. Technical report, University of Maryland.

Goldberg, P. K. and N. Pavcnik (2005). Trade, wages, and the political economy of trade protection: evidence from the Colombian trade reforms. Journal of International Economics 66(1), 75-105.

Goldberg, P. K. and N. Pavcnik (2007). Distributional effects of globalization in developing countries. Journal of Economic Literature 45, 39-92. 
Hamilton, B. and J. Whalley (1984). Efficiency and distributional implications of global restrictions on labour mobility: Calculations and policy implications. Journal of Development Economics 14(1), 61-75.

Handley, K. and N. Limao (2013). Policy uncertainty, trade and welfare: Theory and evidence for china and the u.s. Working Paper 19376, National Bureau of Economic Research.

Hasan, R., D. Mitra, P. Ranjan, and R. N. Ahsan (2012). Trade liberalization and unemployment: Theory and evidence from India. Journal of Development Economics 97(2), 269-280.

Kovak, B. K. (2013). Regional effects of trade reform: What is the correct measure of liberalization? The American Economic Review 103(5), 1960-1976.

Molloy, R., C. L. Smith, and A. Wozniak (2011). Internal migration in the us: Updated facts and recent trends. Journal of Economic Perspectives 25, 173-196.

Nunn, N. (2007). Relationship-specificity, incomplete contracts and the pattern of trade. Quarterly Journal of Economics 122, 569-600.

Pierce, J. R. and P. K. Schott (2015). The surprisingly swift decline of US manufacturing employment. Technical report, National Bureau of Economic Research.

Tombe, T. and X. Zhu (2015). Trade, migration and productivity: A quantitative analysis of China. Technical report, University of Toronto.

Topalova, P. (2010). Factor immobility and regional impacts of trade liberalization: Evidence on poverty from india. American Economic Journal: Applied Economics 2(4), $1-41$. 


\section{A Data Appendix}

\section{A.1 Data Sources}

This section goes over the details of the data used in this paper, as well as the key variables for the empirical analysis. There are 3 main sources of data: China's Population Census, China Custom Data (CCD), and tariff rates from the World Integrated Trade Solution (WITS) dataset. In addition, the industry skill intensity data is aggregated from the "Chinese Industrial Enterprises Database".

\section{A.1.1 China Custom Data: 1997-2006}

We use China Custom Data (CCD, also called China Import and Export Data) from 1997 to 2006 to construct the the export basket of each prefecture. China Custom Data is an annual HS-based transaction-level data compiled by the General Administration of Customs of China. It records information on each import/export transaction, and the variables relevant for our analysis include commodity code (HS 6-digit), partner country, firm type, firm location at the prefecture level, import/export type, transaction value (in USD), and transaction types.

\section{A.1.2 Skill Intensity}

We use HS 6-digit level factor intensity data aggregated from the "2004 Chinese Manufacturing Firm Data". It is also known as "Chinese Industrial Enterprises Database"), which is a firm-level data, collected yearly by China's National Bureau of Statistics. The survey includes all industrial firms that are either state-owned, or are non-state firms with sales above 5 million RMB. It contains the management data of more than 300,000 industrial enterprises above the designated size in China. The data covers the indexes including industry, output value, export delivery value, number of employers, wage payments, profit and tax etc.. 


\section{A.1.3 Census of China: 1990, 2000, 2005}

The migration data comes form the population census of China, conducted by the National Bureau of Statistics (NBS). We use samples from the 1990, 2000 and 2005 waves. The population census of China documents detailed information on individual's location, hukou status and migration history, among other individual characteristics. 
Figure 1: Prefecture level partial migration rates, Census 2000

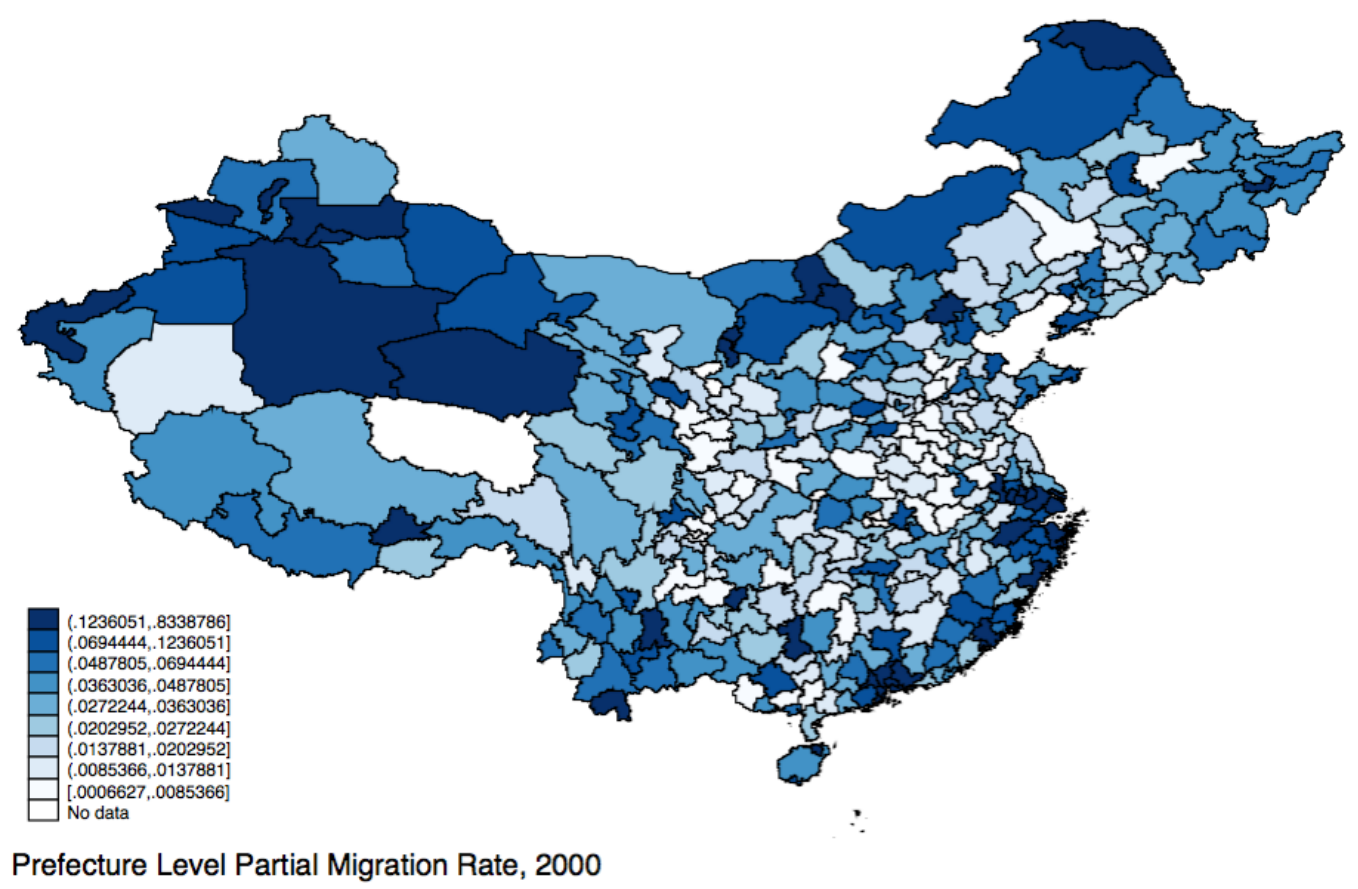


Figure 2: Prefecture level partial AND full migration rates, Census 2000

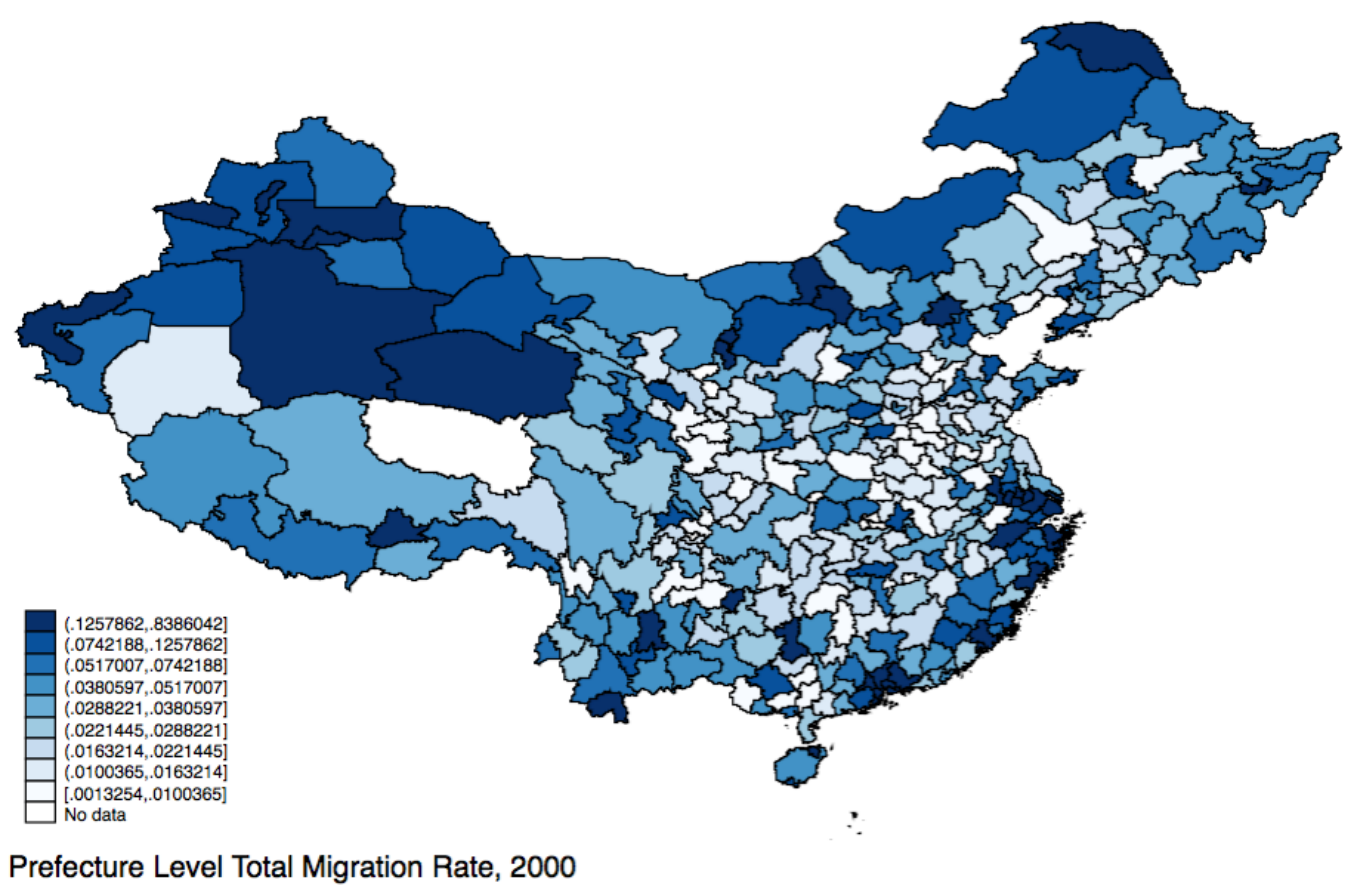


Figure 3: Prefecture level partial migration rates, Census 2005

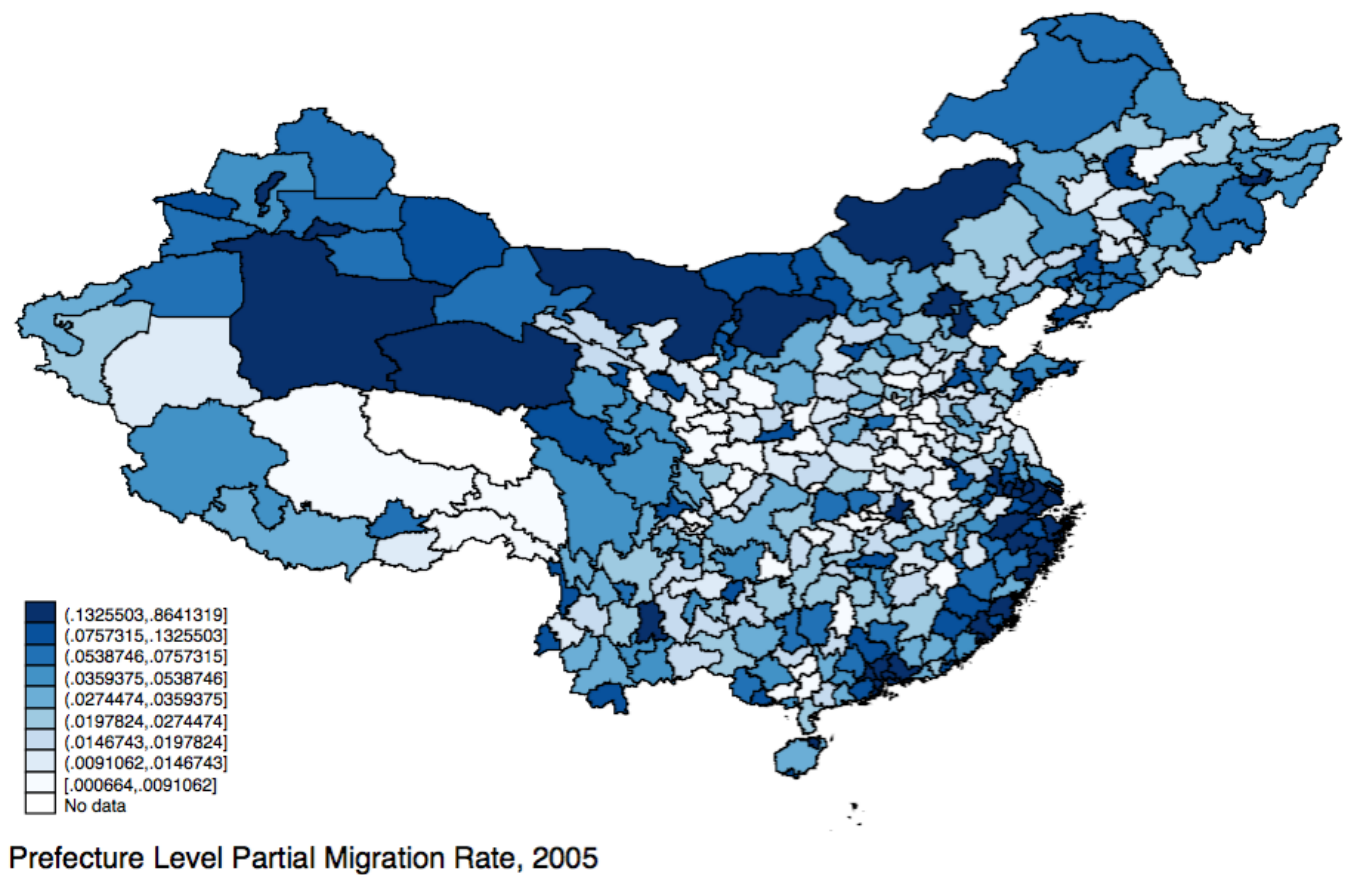

Prefecture Level Partial Migration Rate, 2005 
Figure 4: Prefecture level partial AND full migration rates, Census 2005

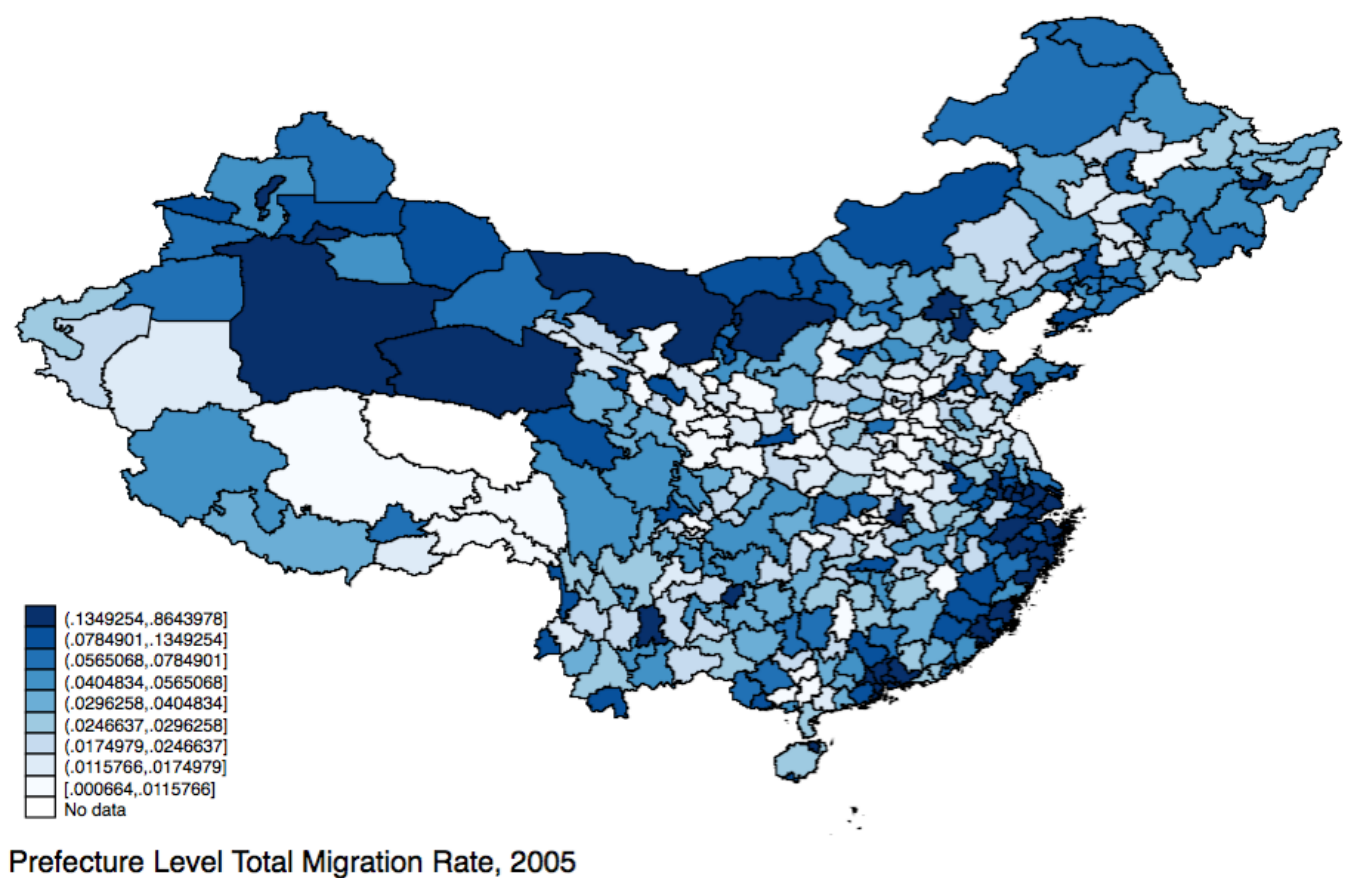

Prefecture Level Total Migration Rate, 2005 
Figure 5: HS 6-digit product level NTR gaps, 1999

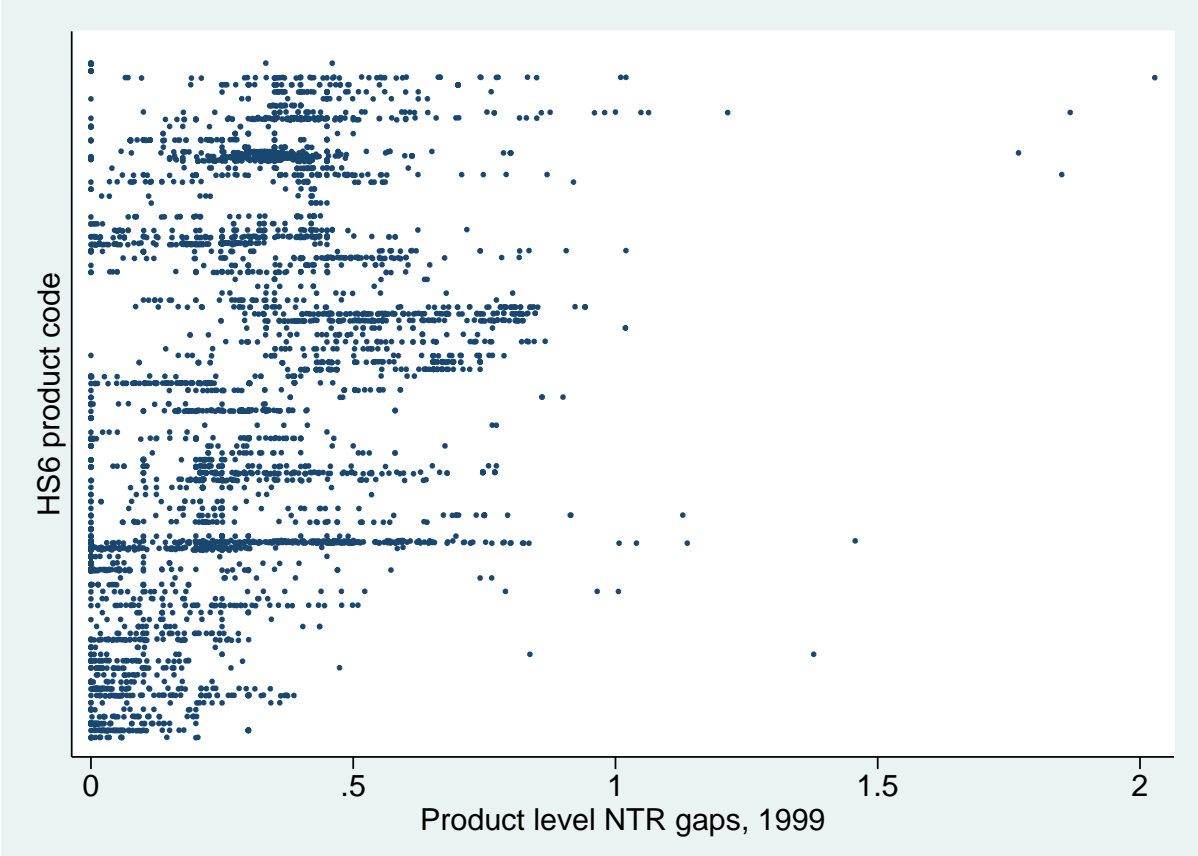

This figure shows the distribution of HS 6-digit product level NTR gaps. 
Figure 6: Prefecture level NTR gaps, 1999

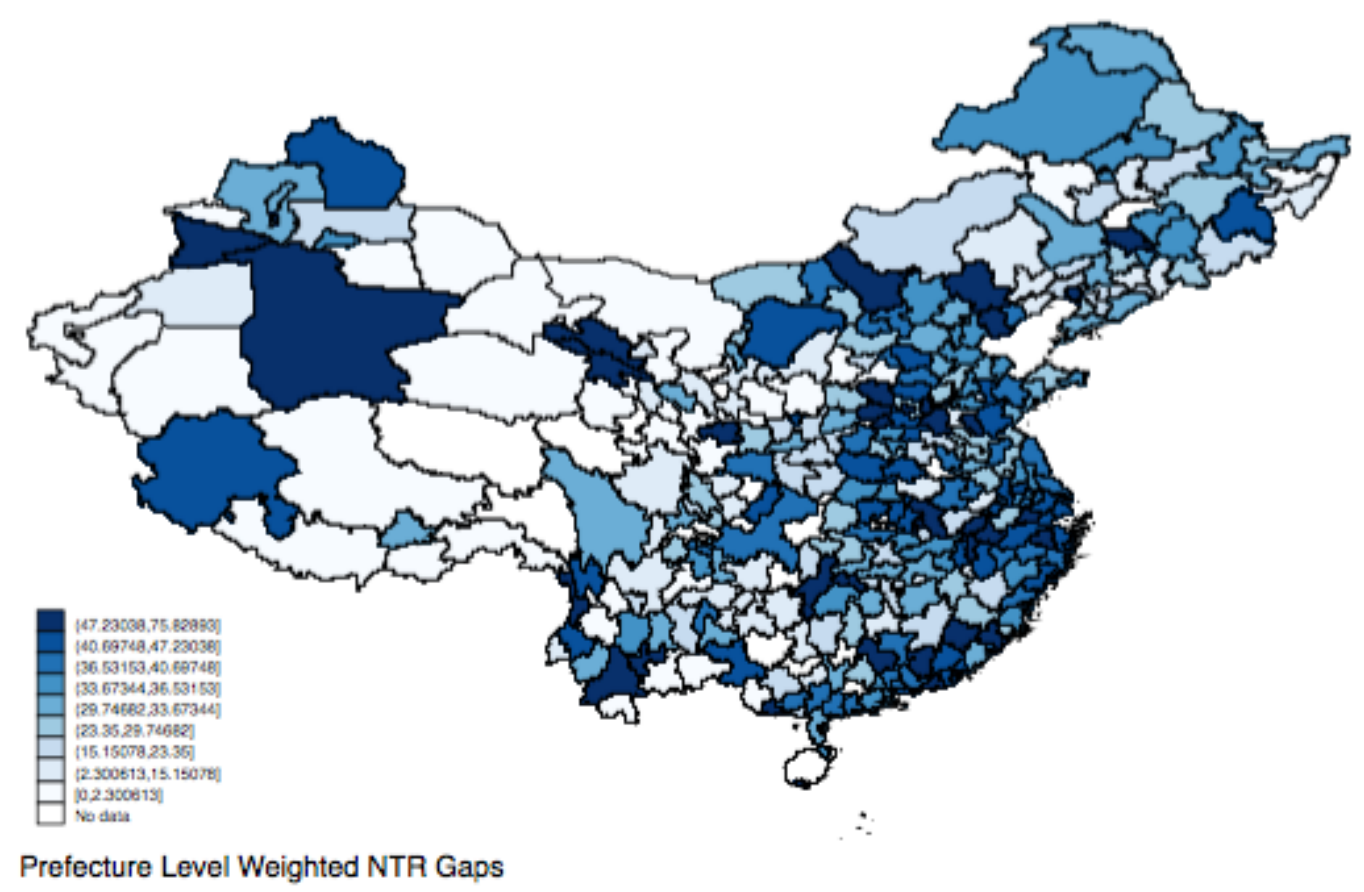

Note: This figure shows the distribution of prefecture level NTR gaps aggregated by using each prefecture's exports to the US. 
Table 1: Internal Migration of Employed Population

\begin{tabular}{|c|c|c|}
\hline $1995-2000$ & Male & Female \\
\hline Interprovincial Migrants of employed population (million) & 17.71 & 13.96 \\
\hline Interprovincial Migration Rate of employed population (\%) & 4.776 & 4.503 \\
\hline Interprovincial Migration Rate of SKILLED employed population (\%) & 4.998 & 4.344 \\
\hline Interprovincial Migration Rate of UNSKILLED employed population (\%) & 4.721 & 4.530 \\
\hline $2000-2005$ & Male & Female \\
\hline Interprovincial Migrants of employed population (million) & 22.72 & 17.95 \\
\hline Interprovincial Migration Rate of employed population (\%) & 6.243 & 5.776 \\
\hline Interprovincial Migration Rate of SKILLED employed population (\%) & 7.037 & 6.297 \\
\hline Interprovincial Migration Rate of UNSKILLED employed population (\%) & 6.023 & 5.673 \\
\hline
\end{tabular}


Table 2: Product Level NTR gaps by skill group, 1999

\begin{tabular}{lccc}
\hline \hline & Unskilled & Skilled & Total \\
\hline Non-NTR rate & 0.410 & 0.298 & 0.349 \\
& $(0.259)$ & $(0.204)$ & $(0.237)$ \\
NTR rate & 0.0543 & 0.0299 & 0.0411 \\
& $(0.0688)$ & $(0.0533)$ & $(0.0621)$ \\
NTR gap & 0.356 & 0.268 & 0.308 \\
& $(0.227)$ & $(0.187)$ & $(0.211)$ \\
\hline \hline
\end{tabular}

This table shows the summary statistics of product level NTR gaps. The first two columns are unskilled and skilled products, respectively. Skill groups are determined by skill intensity information drawn from the 2004 Industrial Census. Non-NTR rates are Smoot-Hawley rates, NTR rates are MFN rates, and NTR gaps are the difference between non-NTR rates and NTR rates. 
Table 3: Summary Statistics of NTR gaps at prefecture level

\begin{tabular}{lcc}
\hline \hline & World Export & US Export \\
\hline Weighted Average NTR gap & 30.58 & 31.73 \\
& $(15.02)$ & $(14.21)$ \\
Weighted Average Skilled NTR gap & 21.91 & 24.99 \\
& $(13.19)$ & $(15.04)$ \\
Weighted Average Unskilled NTR gap & 34.72 & 33.66 \\
& $(15.58)$ & $(15.45)$ \\
Simple Average NTR gap & 34.17 & 34.46 \\
& $(9.283)$ & $(9.576)$ \\
Simple Average Skilled NTR gap & 25.82 & 27.03 \\
& $(9.637)$ & $(12.61)$ \\
Simple Average Unskilled NTR gap & 37.17 & 35.84 \\
& $(10.71)$ & $(11.60)$ \\
\hline \hline
\end{tabular}

Note: The NTR gaps in the first columns are built using information from the prefecture export basket towards the entire world; in the second we instead use information from the export basket towards the United States. Skilled (unskilled) NTR gaps only includes products that are skilled (unskilled) labor intensive. 
Table 4: Summary statistics of prefecture level panel data

\begin{tabular}{|c|c|c|}
\hline & 2000 & 2005 \\
\hline Inter- and Intra-provincial Partial PLUS Full Migration Rate (\%) & $\begin{array}{c}7.880 \\
(13.05)\end{array}$ & $\begin{array}{c}10.25 \\
(15.81)\end{array}$ \\
\hline Inter-provincial Partial PLUS Full Migration Rate (\%) & $\begin{array}{c}4.756 \\
(10.19)\end{array}$ & $\begin{array}{c}6.294 \\
(12.70)\end{array}$ \\
\hline Inter- and Intra-provincialPartial Migration Rate (\%) & $\begin{array}{c}7.567 \\
(13.00)\end{array}$ & $\begin{array}{c}9.889 \\
(15.84)\end{array}$ \\
\hline Inter-provincial Full Migration Rate (\%) & $\begin{array}{c}0.377 \\
(0.517)\end{array}$ & $\begin{array}{c}0.428 \\
(0.558)\end{array}$ \\
\hline Weighted NTR gap (\%) & $\begin{array}{c}0 \\
(0)\end{array}$ & $\begin{array}{c}30.54 \\
(14.50)\end{array}$ \\
\hline Contract Intensity (\%) & $\begin{array}{c}0 \\
(0)\end{array}$ & $\begin{array}{c}41.91 \\
(10.56)\end{array}$ \\
\hline MFA Quota Bound (\%) & $\begin{array}{c}0 \\
(0)\end{array}$ & $\begin{array}{c}12.46 \\
(13.02)\end{array}$ \\
\hline Tariff Abroad (\%) & $\begin{array}{c}4.333 \\
(3.321)\end{array}$ & $\begin{array}{c}3.948 \\
(3.089)\end{array}$ \\
\hline Import Tariff (\%) & $\begin{array}{c}13.33 \\
(6.769)\end{array}$ & $\begin{array}{c}7.027 \\
(3.101)\end{array}$ \\
\hline Production Subsidy (\%) & $\begin{array}{c}0.842 \\
(2.057)\end{array}$ & $\begin{array}{c}0.536 \\
(1.742)\end{array}$ \\
\hline
\end{tabular}

Note: This table summarizes migration measures and trade barriers in 2000 and 2005, at the prefecture level. First 4 rows list migration rates calculated as the shares of migrants in a prefecture's population. Rows 5-10 list measures of trade barriers considered in the main regression specification. Tariff Abroad is the weighted average tariff rate a prefecture faces at export markets, given its export basket. Import tariff is the weighted average import tariff a prefecture imposes on imported goods, given its import basket. Production subsidy measures the share of local production subsidized. Uncertainty of U.S. tariff rates, investment barriers, and MFA quota are trade barriers that were eliminated as China joined WTO; thus we construct them to measure the size of reduction in trade barriers. More specifically, Weighted NTR gaps measure the reduction in uncertainty of U.S. tariff rates. Contract Intensity measures reduction in investment barriers; specifically, it measures the share of intermediate inputs that require relationship-specific investments. MFA Quota Bound measures the relaxation of MFA quotas; specifically, it measures the share of textile export that would have faced binding MFA quota were not for China's WTO-accession. All measures of trade barriers are aggregated from the product/industry/firm level to prefecture level. 
Table 5: $\log$ Exports to US: by product and by prefecture

\begin{tabular}{|c|c|c|c|c|c|c|}
\hline & \multicolumn{3}{|c|}{$\log$ Exp to US by product } & \multicolumn{3}{|c|}{ log Exp to US by prefecture } \\
\hline & (1) & $(2)$ & (3) & (4) & $(5)$ & $(6)$ \\
\hline Post x NTR gap & $\begin{array}{c}0.027 \\
(0.003)^{* * *}\end{array}$ & $\begin{array}{c}0.027 \\
(0.003)^{* * *}\end{array}$ & $\begin{array}{c}0.025 \\
(0.003)^{* * *}\end{array}$ & $\begin{array}{c}0.007 \\
(0.003)^{* * *}\end{array}$ & $\begin{array}{c}0.008 \\
(0.003)^{* * *}\end{array}$ & $\begin{array}{c}0.007 \\
(0.003)^{* * *}\end{array}$ \\
\hline Post x Contract Intensity & & $\begin{array}{l}0.004 \\
(0.004)\end{array}$ & $\begin{array}{l}0.004 \\
(0.004)\end{array}$ & & $\begin{array}{l}-0.001 \\
(0.004)\end{array}$ & $\begin{array}{r}-0.001 \\
(0.004)\end{array}$ \\
\hline US Tariff & & & $\begin{array}{l}-0.057 \\
(0.023)^{* *}\end{array}$ & & & $\begin{array}{l}-0.003 \\
(0.004)\end{array}$ \\
\hline Tariff Abroad & & & $\begin{array}{l}-0.008 \\
(0.007)\end{array}$ & & & $\begin{array}{l}-0.004 \\
(0.004)\end{array}$ \\
\hline Import Tariff & & & $\begin{array}{l}-0.008 \\
(0.009)\end{array}$ & & & $\begin{array}{l}-0.007 \\
(0.006)\end{array}$ \\
\hline$R^{2}$ & 0.79 & 0.79 & 0.79 & 0.96 & 0.96 & 0.96 \\
\hline$N$ & 30,401 & 30,401 & 30,248 & 2,010 & 2,010 & 2,010 \\
\hline Product FE; Time FE & YES & YES & YES & & & \\
\hline $\begin{array}{l}\text { Prefecture FE; Time FE } \\
\text { SE }\end{array}$ & Clustered & Clustered & Clustered & $\begin{array}{c}\text { YES } \\
\text { Clustered }\end{array}$ & $\begin{array}{c}\text { YES } \\
\text { Clustered }\end{array}$ & $\begin{array}{c}\text { YES } \\
\text { Clustered }\end{array}$ \\
\hline
\end{tabular}

Note: The dependent variable is the annual log export to the US. Huber-White robust SEs in parentheses are clustered at the product level for columns (1)-(3) and at the prefecture level for columns (4)-(6). 
Table 6: Migration rate of all migrants (full PLUS partial)

\begin{tabular}{|c|c|c|c|}
\hline & $(1)$ & $(2)$ & $(3)$ \\
\hline Post x NTR gap & $\begin{array}{c}0.049 \\
(0.014)^{* * *}\end{array}$ & $\begin{array}{c}0.043 \\
(0.015)^{* * *}\end{array}$ & $\begin{array}{c}0.043 \\
(0.015)^{* * *}\end{array}$ \\
\hline Post x Contract Intensity & & $\begin{array}{c}0.027 \\
(0.017)\end{array}$ & $\begin{array}{c}0.030 \\
(0.017)^{*}\end{array}$ \\
\hline Post x $\Delta$ Tariff Abroad & & & $\begin{array}{l}0.019 \\
(0.057)\end{array}$ \\
\hline Post x $\Delta$ Import Tariff & & & $\begin{array}{l}-0.023 \\
(0.027)\end{array}$ \\
\hline Post x MFA Quota Bound & & & $\begin{array}{l}-0.000 \\
(0.014)\end{array}$ \\
\hline Production Subsidy & & & $\begin{array}{l}-0.004 \\
(0.146)\end{array}$ \\
\hline$R^{2}$ & 0.96 & 0.96 & 0.96 \\
\hline$N$ & 672 & 672 & 672 \\
\hline Prefecture FE; Time FE & YES & YES & YES \\
\hline $\mathrm{SE}$ & Robust & Robust & Robust \\
\hline
\end{tabular}

Note: Robust standard errors in parentheses in all regressions. The dependent variable is the migration rate of full (cross-province) migrants and partial (cross-province and cross-county) migrants. The sample includes 336 prefectures, observed at 2000 and 2005. The prefecture-level import and export tariff rates are weighted using the trade basket of each prefecture. The DID terms are constructed using a time dummy "Post" interacted with corresponding trade shocks. 
Table 7: Migration rates of provincial migrants

\begin{tabular}{|c|c|c|c|c|c|c|c|c|c|}
\hline & \multicolumn{3}{|c|}{ Prov PM+FM } & \multicolumn{3}{|c|}{ Prov Partial Migrants } & \multicolumn{3}{|c|}{ Prov Full Migrants } \\
\hline & (1) & (2) & $(3)$ & (4) & $(5)$ & (6) & (7) & (8) & (9) \\
\hline Post x NTR gap & $\begin{array}{c}0.034 \\
(0.011)^{* * *}\end{array}$ & $\begin{array}{c}0.031 \\
(0.012)^{* * *}\end{array}$ & $\begin{array}{c}0.032 \\
(0.013)^{* *}\end{array}$ & $\begin{array}{c}0.034 \\
(0.011)^{* * *}\end{array}$ & $\begin{array}{c}0.029 \\
(0.012)^{* *}\end{array}$ & $\begin{array}{c}0.030 \\
(0.012)^{* *}\end{array}$ & $\begin{array}{l}-0.001 \\
(0.002)\end{array}$ & $\begin{array}{l}0.002 \\
(0.003)\end{array}$ & $\begin{array}{l}0.002 \\
(0.003)\end{array}$ \\
\hline Post x Contract Intensity & & $\begin{array}{l}0.009 \\
(0.014)\end{array}$ & $\begin{array}{l}0.011 \\
(0.015)\end{array}$ & & $\begin{array}{l}0.020 \\
(0.014)\end{array}$ & $\begin{array}{l}0.021 \\
(0.015)\end{array}$ & & $\begin{array}{c}-0.011 \\
(0.003)^{* * *}\end{array}$ & $\begin{array}{c}-0.010 \\
(0.003)^{* * *}\end{array}$ \\
\hline Post x Tariff Abroad & & & $\begin{array}{l}-0.010 \\
(0.042)\end{array}$ & & & $\begin{array}{l}-0.015 \\
(0.040)\end{array}$ & & & $\begin{array}{c}0.006 \\
(0.010)\end{array}$ \\
\hline Post x Import Tariff & & & $\begin{array}{l}-0.018 \\
(0.023)\end{array}$ & & & $\begin{array}{l}-0.008 \\
(0.022)\end{array}$ & & & $\begin{array}{l}-0.010 \\
(0.006)^{*}\end{array}$ \\
\hline Post x MFA Quota Bound & & & $\begin{array}{l}-0.004 \\
(0.014)\end{array}$ & & & $\begin{array}{l}-0.003 \\
(0.012)\end{array}$ & & & $\begin{array}{l}-0.001 \\
(0.003)\end{array}$ \\
\hline Production Subsidy & & & $\begin{array}{l}-0.022 \\
(0.109)\end{array}$ & & & $\begin{array}{l}-0.014 \\
(0.109)\end{array}$ & & & $\begin{array}{l}-0.009 \\
(0.014)\end{array}$ \\
\hline$R^{2}$ & 0.96 & 0.96 & 0.96 & 0.96 & 0.96 & 0.96 & 0.67 & 0.68 & 0.69 \\
\hline$N$ & 672 & 672 & 672 & 672 & 672 & 672 & 672 & 672 & 672 \\
\hline Prefecture FE; Time FE & YES & YES & YES & YES & YES & YES & YES & YES & YES \\
\hline $\mathrm{SE}$ & Robust & Robust & Robust & Robust & Robust & Robust & Robust & Robust & Robust \\
\hline
\end{tabular}

Note: Robust standard errors in parentheses in all regressions. The dependent variables are the migration rate of cross-province full and partial migrants (Columns (1)-(3)), all (cross-province and cross-county) partial migrants (Columns (4)-(6)), and cross-province full migrants (Columns (7)(9)). The sample includes 336 prefectures, observed at 2000 and 2005. The prefecture-level import and export tariff rates are weighted using the trade basket of each prefecture. The DID terms are constructed using a time dummy "Post" interacted with corresponding trade shocks. 
Table 8: Labor Market Outcomes

\begin{tabular}{|c|c|c|c|c|c|c|}
\hline & \multicolumn{3}{|c|}{ Employment Rate } & \multicolumn{3}{|c|}{ Working Hours } \\
\hline & (1) & $(2)$ & $(3)$ & $(4)$ & $(5)$ & $(6)$ \\
\hline Post x NTR gap & $\begin{array}{l}0.001 \\
(0.006)\end{array}$ & $\begin{array}{l}-0.003 \\
(0.006)\end{array}$ & $\begin{array}{l}-0.002 \\
(0.007)\end{array}$ & $\begin{array}{c}0.081 \\
(0.023)^{* * *}\end{array}$ & $\begin{array}{c}0.064 \\
(0.024)^{* * *}\end{array}$ & $\begin{array}{c}0.057 \\
(0.024)^{* *}\end{array}$ \\
\hline Post x Contract Intensity & & $\begin{array}{c}0.017 \\
(0.007)^{* * *}\end{array}$ & $\begin{array}{c}0.017 \\
(0.007)^{* *}\end{array}$ & & $\begin{array}{c}0.072 \\
(0.023)^{* * *}\end{array}$ & $\begin{array}{c}0.069 \\
(0.024)^{* * *}\end{array}$ \\
\hline Post x $\Delta$ Tariff Abroad & & & $\begin{array}{c}0.049 \\
(0.067)\end{array}$ & & & $\begin{array}{c}0.297 \\
(0.195)\end{array}$ \\
\hline Post x $\Delta$ Import Tariff & & & $\begin{array}{l}-0.002 \\
(0.014)\end{array}$ & & & $\begin{array}{l}0.025 \\
(0.062)\end{array}$ \\
\hline Post x MFA Quota Bound & & & $\begin{array}{l}-0.003 \\
(0.008)\end{array}$ & & & $\begin{array}{l}0.024 \\
(0.026)\end{array}$ \\
\hline Production Subsidy & & & $\begin{array}{l}0.058 \\
(0.040)\end{array}$ & & & $\begin{array}{l}0.005 \\
(0.296)\end{array}$ \\
\hline$R^{2}$ & 0.83 & 0.83 & 0.83 & 0.70 & 0.70 & 0.71 \\
\hline$N$ & 672 & 672 & 672 & 672 & 672 & 672 \\
\hline Prefecture FE; Time FE & YES & YES & YES & YES & YES & YES \\
\hline $\mathrm{SE}$ & Robust & Robust & Robust & Robust & Robust & Robust \\
\hline
\end{tabular}

Note: Robust standard errors in parentheses in all regressions. The dependent variable are the share of employed in percentage points, and weekly working hours. The sample includes 336 prefectures, observed at 2000 and 2005. The prefecture-level import and export tariff rates are weighted using the trade basket of each prefecture. The DID terms are constructed using a time dummy "Post" interacted with corresponding trade shocks. 
Table 9: Robustness Check: Migration rate of all migrants (full PLUS partial), using alternative NTR gaps

\begin{tabular}{|c|c|c|c|c|c|c|c|c|c|}
\hline & \multicolumn{3}{|c|}{ Unweighted Exports to the US } & \multicolumn{3}{|c|}{ Weighted Exports to the World } & \multicolumn{3}{|c|}{ Unweighted Exports to the World } \\
\hline & $(1)$ & $(2)$ & $(3)$ & $(4)$ & $(5)$ & $(6)$ & $(7)$ & (8) & $(9)$ \\
\hline Post x NTR gap & $\begin{array}{c}0.043 \\
(0.015)^{* * *}\end{array}$ & $\begin{array}{c}0.035 \\
(0.017)^{* *}\end{array}$ & $\begin{array}{c}0.045 \\
(0.019)^{* *}\end{array}$ & $\begin{array}{c}0.058 \\
(0.018)^{* * *}\end{array}$ & $\begin{array}{c}0.052 \\
(0.020)^{* * *}\end{array}$ & $\begin{array}{c}0.054 \\
(0.021)^{* *}\end{array}$ & $\begin{array}{c}0.060 \\
(0.021)^{* * *}\end{array}$ & $\begin{array}{c}0.051 \\
(0.026)^{* *}\end{array}$ & $\begin{array}{c}0.066 \\
(0.029)^{* *}\end{array}$ \\
\hline Post x Contract Intensity & & $\begin{array}{c}0.023 \\
(0.020)\end{array}$ & $\begin{array}{c}0.023 \\
(0.020)\end{array}$ & & $\begin{array}{c}0.019 \\
(0.020)\end{array}$ & $\begin{array}{c}0.021 \\
(0.021)\end{array}$ & & $\begin{array}{c}0.016 \\
(0.022)\end{array}$ & $\begin{array}{c}0.014 \\
(0.022)\end{array}$ \\
\hline Post x Tariff Abroad & & & $\begin{array}{l}-0.007 \\
(0.067)\end{array}$ & & & $\begin{array}{l}0.023 \\
(0.058)\end{array}$ & & & $\begin{array}{l}0.009 \\
(0.066)\end{array}$ \\
\hline Post x Import Tariff & & & $\begin{array}{l}-0.026 \\
(0.031)\end{array}$ & & & $\begin{array}{l}-0.015 \\
(0.027)\end{array}$ & & & $\begin{array}{l}-0.023 \\
(0.029)\end{array}$ \\
\hline Post x MFA Quota Bound & & & $\begin{array}{r}-0.018 \\
(0.016)\end{array}$ & & & $\begin{array}{l}-0.009 \\
(0.014)\end{array}$ & & & $\begin{array}{l}-0.019 \\
(0.016)\end{array}$ \\
\hline Production Subsidy & & & $\begin{array}{l}-0.022 \\
(0.146)\end{array}$ & & & $\begin{array}{l}-0.000 \\
(0.143)\end{array}$ & & & $\begin{array}{c}-0.018 \\
(0.138)\end{array}$ \\
\hline$R^{2}$ & 0.96 & 0.96 & 0.96 & 0.96 & 0.96 & 0.96 & 0.96 & 0.96 & 0.96 \\
\hline$N$ & 672 & 672 & 672 & 672 & 672 & 672 & 672 & 672 & 672 \\
\hline Prefecture FE; Time FE & YES & YES & YES & YES & YES & YES & YES & YES & YES \\
\hline $\mathrm{SE}$ & Robust & Robust & Robust & Robust & Robust & Robust & Robust & Robust & Robust \\
\hline
\end{tabular}

Note: This table shows the results of the baseline specification using alternative definitions of NTR gaps. In the left three columns, prefecture-level NTR gaps are simple averages of NTR gaps of products exported to the US, and the prefecture-level import and export tariff rates are simple averages of tariff rates of products imported and exported by each prefecture. In the right three columns, prefecture-level NTR gaps are weighted averages of NTR gaps of products exported to the world, and the prefecture-level import and export tariff rates are weighted averages of tariff rates of products imported and exported by each prefecture. The prefecture-level import and export tariff rates are weighted using the trade basket of each prefecture. Robust standard errors in parentheses in all regressions. The dependent variable is the migration rate of full (cross-province) migrants and partial (cross-province and cross-county) migrants. The sample includes 336 prefectures, observed at 2000 and 2005. The DID terms are constructed using a time dummy "Post" interacted with corresponding trade shocks. 
Table 10: Placebo: Migration rate of all migrants (full PLUS partial)

\begin{tabular}{|c|c|c|c|}
\hline & (1) & $(2)$ & $(3)$ \\
\hline Post x NTR gap & $\begin{array}{c}0.047 \\
(0.027)^{*}\end{array}$ & $\begin{array}{c}0.038 \\
(0.024)\end{array}$ & $\begin{array}{l}0.032 \\
(0.025)\end{array}$ \\
\hline Post x Contract Intensity & & $\begin{array}{c}0.039 \\
(0.050)\end{array}$ & $\begin{array}{l}0.030 \\
(0.050)\end{array}$ \\
\hline Post x $\Delta$ Tariff Abroad & & & $\begin{array}{l}-0.068 \\
(0.146)\end{array}$ \\
\hline Post x $\Delta$ Import Tariff & & & $\begin{array}{l}-0.072 \\
(0.041)^{*}\end{array}$ \\
\hline Post x MFA Quota Bound & & & $\begin{array}{l}-0.018 \\
(0.033)\end{array}$ \\
\hline$R^{2}$ & 0.83 & 0.83 & 0.83 \\
\hline$N$ & 530 & 530 & 530 \\
\hline Prefecture FE; Time FE & YES & YES & YES \\
\hline $\mathrm{SE}$ & Robust & Robust & Robust \\
\hline
\end{tabular}

Note: This table shows the placebo test using migration flows between 1990 and 2000 and test whether they changes in anticipation to trade liberalizations between 2000-2005. The dependent variable is the migration rates of all migrants. The sample includes workers in 265 prefectures, observed at 1990 and 2000. Not all prefectures are included in the placebo tests due to reforms in administrative units. We deal with this concordance issue by only including prefectures whose borders stayed the same. The prefecture-level import and export tariff rates in 2000 and 2005 are weighted using the trade basket of the skilled-labor-intensive sectors in each prefecture. The DID terms are constructed using a time dummy "Post", indicating the year 2000, interacted with trade shocks. 
Table 11: Placebo: Migration rates

\begin{tabular}{|c|c|c|c|c|c|c|}
\hline & \multicolumn{3}{|c|}{ Partial Migrants } & \multicolumn{3}{|c|}{ Full Migrants } \\
\hline & (1) & $(2)$ & $(3)$ & $(4)$ & (5) & (6) \\
\hline Post x NTR gap & $\begin{array}{c}0.047 \\
(0.027)^{*}\end{array}$ & $\begin{array}{c}0.039 \\
(0.024)\end{array}$ & $\begin{array}{c}0.033 \\
(0.026)\end{array}$ & $\begin{array}{l}0.000 \\
(0.004)\end{array}$ & $\begin{array}{l}-0.001 \\
(0.004)\end{array}$ & $\begin{array}{l}-0.001 \\
(0.005)\end{array}$ \\
\hline Post x Contract Intensity & & $\begin{array}{c}0.034 \\
(0.049)\end{array}$ & $\begin{array}{c}0.026 \\
(0.049)\end{array}$ & & $\begin{array}{c}0.004 \\
(0.006)\end{array}$ & $\begin{array}{l}0.004 \\
(0.007)\end{array}$ \\
\hline Post x $\Delta$ Tariff Abroad & & & $\begin{array}{l}-0.090 \\
(0.150)\end{array}$ & & & $\begin{array}{l}0.023 \\
(0.055)\end{array}$ \\
\hline Post x $\Delta$ Import Tariff & & & $\begin{array}{l}-0.072 \\
(0.040)^{*}\end{array}$ & & & $\begin{array}{l}-0.001 \\
(0.007)\end{array}$ \\
\hline Post x MFA Quota Bound & & & $\begin{array}{l}-0.022 \\
(0.033)\end{array}$ & & & $\begin{array}{l}0.004 \\
(0.005)\end{array}$ \\
\hline$R^{2}$ & 0.83 & 0.83 & 0.83 & 0.55 & 0.55 & 0.55 \\
\hline$N$ & 530 & 530 & 530 & 530 & 530 & 530 \\
\hline Prefecture FE; Time FE & YES & YES & YES & YES & YES & YES \\
\hline $\mathrm{SE}$ & Robust & Robust & Robust & Robust & Robust & Robust \\
\hline
\end{tabular}

Note: This table shows the placebo test using migration flows between 1990 and 2000 and test whether they changes in anticipation to trade liberalizations between 2000-2005. The dependent variable is the migration rates of partial migrants (Columns (1)-(3)) and full migrants (Columns (4)-(6)). The sample includes workers in 265 prefectures, observed at 1990 and 2000. Not all prefectures are included in the placebo tests due to reforms in administrative units. We deal with this concordance issue by only including prefectures whose borders stayed the same. The prefecturelevel import and export tariff rates in 2000 and 2005 are weighted using the trade basket of the skilled-labor-intensive sectors in each prefecture. The DID terms are constructed using a time dummy "Post", indicating the year 2000, interacted with trade shocks. 
Table 12: Migration rate of all migrants (full PLUS partial); skill-specific; same NTR gap

\begin{tabular}{|c|c|c|c|c|c|c|}
\hline & \multicolumn{3}{|c|}{ Unskilled } & \multicolumn{3}{|c|}{ Skilled } \\
\hline & (1) & $(2)$ & $(3)$ & (4) & $(5)$ & (6) \\
\hline Post x NTR gap & $\begin{array}{c}0.035 \\
(0.016)^{* *}\end{array}$ & $\begin{array}{l}0.026 \\
(0.017)\end{array}$ & $\begin{array}{l}0.027 \\
(0.017)\end{array}$ & $\begin{array}{c}0.081 \\
(0.026)^{* * *}\end{array}$ & $\begin{array}{c}0.087 \\
(0.028)^{* * *}\end{array}$ & $\begin{array}{c}0.084 \\
(0.030)^{* * *}\end{array}$ \\
\hline Post x Contract Intensity & & $\begin{array}{c}0.038 \\
(0.019)^{* *}\end{array}$ & $\begin{array}{c}0.037 \\
(0.020)^{*}\end{array}$ & & $\begin{array}{c}-0.026 \\
(0.037)\end{array}$ & $\begin{array}{r}-0.001 \\
(0.031)\end{array}$ \\
\hline Post x $\Delta$ Tariff Abroad & & & $\begin{array}{l}-0.155 \\
(0.183)\end{array}$ & & & $\begin{array}{l}0.439 \\
(0.288)\end{array}$ \\
\hline Post x $\Delta$ Import Tariff & & & $\begin{array}{l}-0.005 \\
(0.027)\end{array}$ & & & $\begin{array}{l}-0.118 \\
(0.113)\end{array}$ \\
\hline Post x MFA Quota Bound & & & $\begin{array}{c}0.002 \\
(0.013)\end{array}$ & & & $\begin{array}{l}-0.027 \\
(0.040)\end{array}$ \\
\hline Production Subsidy & & & $\begin{array}{c}0.022 \\
(0.138)\end{array}$ & & & $\begin{array}{l}-0.574 \\
(0.385)\end{array}$ \\
\hline$R^{2}$ & 0.96 & 0.96 & 0.96 & 0.88 & 0.88 & 0.89 \\
\hline$N$ & 666 & 666 & 666 & 666 & 666 & 666 \\
\hline Prefecture FE; Time FE & YES & YES & YES & YES & YES & YES \\
\hline $\mathrm{SE}$ & Robust & Robust & Robust & Robust & Robust & Robust \\
\hline
\end{tabular}

Note: Robust standard errors in parentheses in all regressions. The dependent variable is the migration rate of full (cross-province) migrants and partial (cross-province and cross-county) migrants by skill groups. The sample includes unskilled sectors (Column (1)-(3)) and unskilled sectors (Column (4)-(6)) in 333 prefectures, observed at 2000 and 2005. Skilled workers are those who completed at least high school education. We use the same NTR gaps and other trade measures both skill groups, ie, NOT skill-specific. The prefecture-level import and export tariff rates are weighted using the trade basket of each prefecture. The DID terms are constructed using a time dummy "Post" interacted with corresponding trade shocks. 
Table 13: Labor Market Outcomes: Work Hours; skill-specific; same NTR gap

\begin{tabular}{|c|c|c|c|c|c|c|}
\hline & \multicolumn{3}{|c|}{ Unskilled } & \multicolumn{3}{|c|}{ Skilled } \\
\hline & $(1)$ & $(2)$ & $(3)$ & $(4)$ & $(5)$ & (6) \\
\hline Post x NTR gap & $\begin{array}{c}0.069 \\
(0.015)^{* * *}\end{array}$ & $\begin{array}{c}0.056 \\
(0.015)^{* * *}\end{array}$ & $\begin{array}{c}0.054 \\
(0.015)^{* * *}\end{array}$ & $\begin{array}{c}0.013 \\
(0.011)\end{array}$ & $\begin{array}{l}0.009 \\
(0.012)\end{array}$ & $\begin{array}{c}0.003 \\
(0.011)\end{array}$ \\
\hline Post x Contract Intensity & & $\begin{array}{c}0.055 \\
(0.017)^{* * *}\end{array}$ & $\begin{array}{c}0.059 \\
(0.017)^{* * *}\end{array}$ & & $\begin{array}{l}0.017 \\
(0.014)\end{array}$ & $\begin{array}{l}0.012 \\
(0.014)\end{array}$ \\
\hline Post x $\Delta$ Tariff Abroad & & & $\begin{array}{c}0.432 \\
(0.152)^{* * *}\end{array}$ & & & $\begin{array}{c}0.356 \\
(0.093)^{* * *}\end{array}$ \\
\hline Post x $\Delta$ Import Tariff & & & $\begin{array}{c}-0.030 \\
(0.037)\end{array}$ & & & $\begin{array}{c}0.052 \\
(0.033)\end{array}$ \\
\hline Post x MFA Quota Bound & & & $\begin{array}{c}0.004 \\
(0.018)\end{array}$ & & & $\begin{array}{c}0.016 \\
(0.013)\end{array}$ \\
\hline Production Subsidy & & & $\begin{array}{l}0.038 \\
(0.191)\end{array}$ & & & $\begin{array}{l}-0.050 \\
(0.115)\end{array}$ \\
\hline$R^{2}$ & 0.71 & 0.72 & 0.72 & 0.68 & 0.68 & 0.70 \\
\hline$N$ & 666 & 666 & 666 & 666 & 666 & 666 \\
\hline Prefecture FE; Time FE & YES & YES & YES & YES & YES & YES \\
\hline $\mathrm{SE}$ & Robust & Robust & Robust & Robust & Robust & Robust \\
\hline
\end{tabular}

Note: Robust standard errors in parentheses in all regressions. The dependent variable is weekly work hours of employed workers in each skill group. The sample includes unskilled sectors (Columns (1)-(3)) and unskilled sectors (Columns (4)-(6)) in 333 prefectures, observed at 2000 and 2005. Skilled workers are those who completed at least high school education. We use the same NTR gaps and other trade measures both skill groups, ie, NOT skill-specific. The prefecture-level import and export tariff rates are weighted using the trade basket of each prefecture. The DID terms are constructed using a time dummy "Post" interacted with corresponding trade shocks. 
Table 14: Labor Market Outcomes: Employment Rate; skill-specific; same NTR gap

\begin{tabular}{|c|c|c|c|c|c|c|}
\hline & \multicolumn{3}{|c|}{ Unskilled } & \multicolumn{3}{|c|}{ Skilled } \\
\hline & (1) & $(2)$ & $(3)$ & $(4)$ & $(5)$ & $(6)$ \\
\hline Post x NTR gap & $\begin{array}{l}0.002 \\
(0.006)\end{array}$ & $\begin{array}{l}-0.003 \\
(0.006)\end{array}$ & $\begin{array}{l}-0.001 \\
(0.007)\end{array}$ & $\begin{array}{l}0.006 \\
(0.009)\end{array}$ & $\begin{array}{l}0.007 \\
(0.009)\end{array}$ & $\begin{array}{l}0.006 \\
(0.010)\end{array}$ \\
\hline Post x Contract Intensity & & $\begin{array}{c}0.021 \\
(0.006)^{* * *}\end{array}$ & $\begin{array}{c}0.021 \\
(0.007)^{* * *}\end{array}$ & & $\begin{array}{l}-0.003 \\
(0.012)\end{array}$ & $\begin{array}{l}-0.001 \\
(0.013)\end{array}$ \\
\hline Post x $\Delta$ Tariff Abroad & & & $\begin{array}{c}0.045 \\
(0.076)\end{array}$ & & & $\begin{array}{l}0.169 \\
(0.197)\end{array}$ \\
\hline Post x $\Delta$ Import Tariff & & & $\begin{array}{l}0.003 \\
(0.017)\end{array}$ & & & $\begin{array}{l}-0.023 \\
(0.020)\end{array}$ \\
\hline Post x MFA Quota Bound & & & $\begin{array}{l}-0.006 \\
(0.008)\end{array}$ & & & $\begin{array}{l}0.004 \\
(0.011)\end{array}$ \\
\hline Production Subsidy & & & $\begin{array}{l}0.045 \\
(0.038)\end{array}$ & & & $\begin{array}{l}0.055 \\
(0.069)\end{array}$ \\
\hline$R^{2}$ & 0.82 & 0.82 & 0.82 & 0.77 & 0.77 & 0.77 \\
\hline$N$ & 666 & 666 & 666 & 666 & 666 & 666 \\
\hline Prefecture FE; Time FE & YES & YES & YES & YES & YES & YES \\
\hline $\mathrm{SE}$ & Robust & Robust & Robust & Robust & Robust & Robust \\
\hline
\end{tabular}

Note: Robust standard errors in parentheses in all regressions. The dependent variable is employment rate by skill group. The sample includes unskilled sectors (Columns (1)-(3)) and unskilled sectors (Columns (4)-(6)) in 333 prefectures, observed at 2000 and 2005. Skilled workers are those who completed at least high school education. We use the same NTR gaps and other trade measures both skill groups, ie, NOT skill-specific. The prefecture-level import and export tariff rates are weighted using the trade basket of each prefecture. The DID terms are constructed using a time dummy "Post" interacted with corresponding trade shocks. 
Table 15: Migration Rate of All Migrants (Full PLUS Partial Unskilled); skill-specific measures

\begin{tabular}{|c|c|c|c|c|c|c|}
\hline & \multicolumn{3}{|c|}{ Unskilled } & \multicolumn{3}{|c|}{ Skilled } \\
\hline & (1) & $(2)$ & $(3)$ & $(4)$ & $(5)$ & $(6)$ \\
\hline Post x NTR gap & $\begin{array}{c}0.031 \\
(0.016)^{*}\end{array}$ & $\begin{array}{l}0.027 \\
(0.017)\end{array}$ & $\begin{array}{l}0.023 \\
(0.017)\end{array}$ & $\begin{array}{c}0.073 \\
(0.025)^{* * *}\end{array}$ & $\begin{array}{c}0.050 \\
(0.025)^{* *}\end{array}$ & $\begin{array}{c}0.050 \\
(0.021)^{* *}\end{array}$ \\
\hline Post x Contract Intensity & & $\begin{array}{l}0.014 \\
(0.017)\end{array}$ & $\begin{array}{l}0.001 \\
(0.021)\end{array}$ & & $\begin{array}{c}0.073 \\
(0.037)^{* *}\end{array}$ & $\begin{array}{c}0.071 \\
(0.035)^{* *}\end{array}$ \\
\hline Post x $\Delta$ Tariff Abroad & & & $\begin{array}{l}-0.279 \\
(0.173)\end{array}$ & & & $\begin{array}{c}0.101 \\
(0.148)\end{array}$ \\
\hline Post x $\Delta$ Import Tariff & & & $\begin{array}{c}0.082 \\
(0.066)\end{array}$ & & & $\begin{array}{l}-0.105 \\
(0.090)\end{array}$ \\
\hline Post x MFA Quota Bound & & & $\begin{array}{l}0.007 \\
(0.009)\end{array}$ & & & $\begin{array}{c}0.013 \\
(0.008)^{*}\end{array}$ \\
\hline Production Subsidy & & & $\begin{array}{l}0.040 \\
(0.132)\end{array}$ & & & $\begin{array}{l}-0.660 \\
(0.360)^{*}\end{array}$ \\
\hline$R^{2}$ & 0.96 & 0.96 & 0.96 & 0.88 & 0.89 & 0.89 \\
\hline$N$ & 666 & 666 & 666 & 666 & 666 & 666 \\
\hline Prefecture FE; Time FE & YES & YES & YES & YES & YES & YES \\
\hline $\mathrm{SE}$ & Robust & Robust & Robust & Robust & Robust & Robust \\
\hline
\end{tabular}

Note: Robust standard errors in parentheses in all regressions. The dependent variable is the migration rate of full (cross-province) migrants and partial (cross-province and cross-county) migrants by skill groups. The sample includes unskilled sectors (Columns (1)-(3)) and unskilled sectors (Columns (4)-(6)) in 333 prefectures, observed at 2000 and 2005. Skilled workers are those who completed at least high school education. We use skill-specific NTR gaps and other trade measures for each skill group. The prefecture-level import and export tariff rates are weighted using the trade basket of each sector-prefecture. The DID terms are constructed using a time dummy "Post" interacted with corresponding trade shocks. 